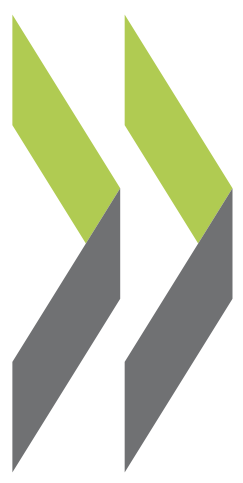

OECD Economics Department Working Papers No. 550

\author{
Housing Markets \\ and Adjustment in Monetary \\ Union
}

Peter Hoeller,

David Rae 
Organisation de Coopération et de Développement Economiques

Organisation for Economic Co-operation and Development

17-Apr-2007

ECONOMICS DEPARTMENT

English - Or. English

HOUSING MARKETS AND ADJUSTMENTS IN MONETARY UNION

Economics Department Working Paper No. 550

by Peter Hoeller and David Rae

All Economics Department Working Papers are available through OECD's internet web site at www.oecd.org/eco/Working_Papers 


\section{ABSTRACT/RÉSUMÉ \\ Housing markets and adjustment in monetary union}

This paper highlights the factors that limit or increase cyclical divergence in the euro area and reviews one policy area that is important in fostering a speedy adjustment to shocks: the transmission of monetary policy via the housing market. A high interest rate sensitivity of housing markets is beneficial as monetary policy is more powerful in damping cyclical fluctuations overall in the euro area. However, housing and mortgage markets still differ widely, leading to asymmetric behaviour of individual countries. Large differences exist in home-ownership rates, financial markets, taxation and supply constraints. Moreover, it is important to have a financial system that can withstand asset price bubbles. In this context, the procyclicality of bank provisioning is of concern as it could lead to a credit crunch and reinforce a downturn. Prudential supervision across the area has become better co-ordinated, but still remains fragmented.

JEL classification: E32; G21; L74

Key words: Monetary union; housing markets.

$* * * * * *$

\section{Marchés immobiliers et ajustement en union monétaire}

Cet article met en évidence les facteurs qui limitent ou renforcent les divergences cycliques au sein de la zone euro et il passe en revue un des aspects importants de la politique économique permettant de promouvoir un ajustement rapide aux chocs : la transmission de la politique monétaire via le marché immobilier. Une forte sensibilité du marché du logement aux taux d'intérêt est bénéfique car la politique monétaire est plus efficace pour amortir les fluctuations cycliques de façon générale dans la zone euro. Cependant, les marchés immobiliers et hypothécaires diffèrent encore fortement, ce qui conduit à des comportements asymétriques des différents pays. Des différences importantes existent du point de vue de la proportion des propriétaires de leur logement, des marchés financiers, de la fiscalité et des contraintes affectant l'offre. De plus, il est important d'avoir un système financier qui peut résister à des bulles financières. Dans ce contexte, le comportement pro-cyclique des banques en matière de provisionnement est problématique car il pourrait conduire à une réduction de l'offre de crédit et un renforcement du ralentissement. La supervision prudentielle dans l'ensemble de la zone est devenue mieux coordonnée, mais elle reste fragmentée.

JEL classification : E32; G21; L74

Mots clés : Union monétaire ; marchés immobiliers.

\section{Copyright $\odot$ OECD, 2007. All rights reserved.}

Application for permission to reproduce or translate all, or part of, this material should be made to: Head of Publications Service, OECD, 2 rue André-Pascal, 75775 PARIS CEDEX 16, France. 
TABLE OF CONTENTS

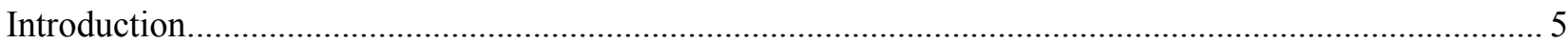

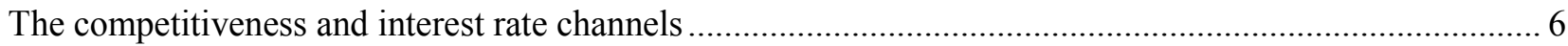

Model simulations of the competitiveness and interest rate channels ................................................ 13

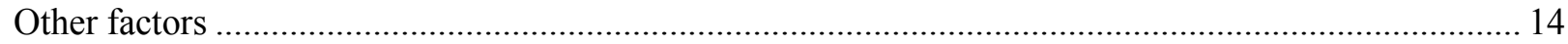

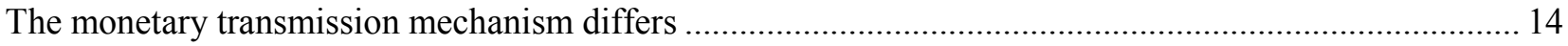

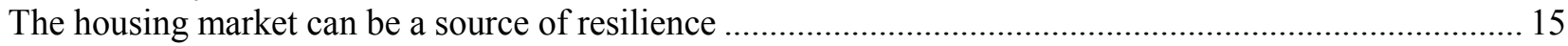

Tax incentives, tight zoning and pro-cyclical bank provisioning tend to reinforce the cycle...................... 19

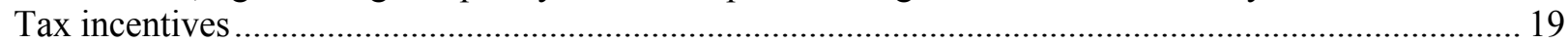

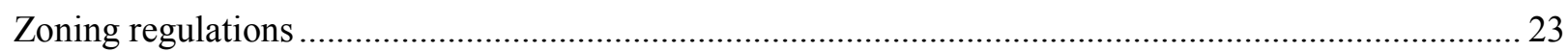

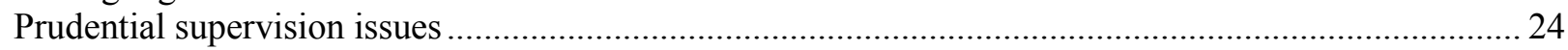

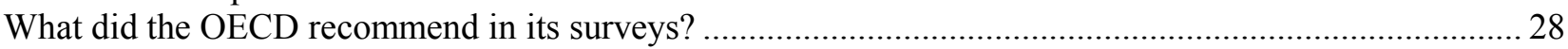

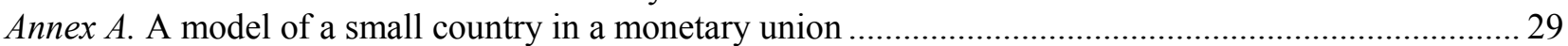

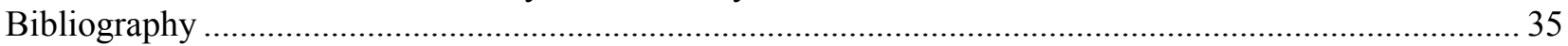

\section{Boxes}

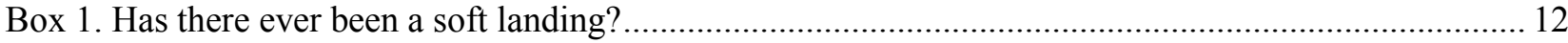

Box 2. Why has the Italian mortgage market been so small? ................................................................. 19

Box 3. What should central banks do about house price booms? ............................................................. 24

\section{Tables}

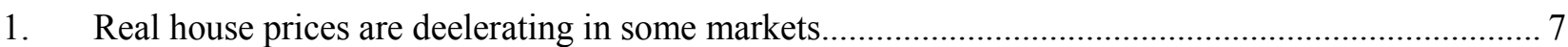

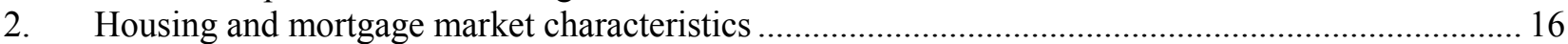

3. Short-term and long-term impact of financial and housing wealth on consumption ........................ 16

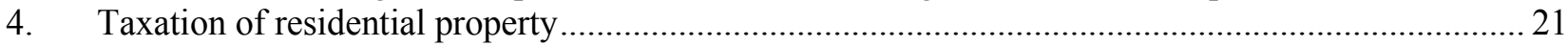

\section{Figures}

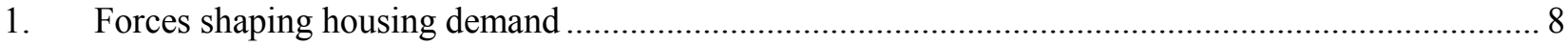

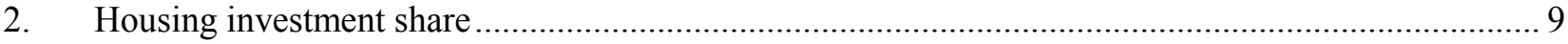

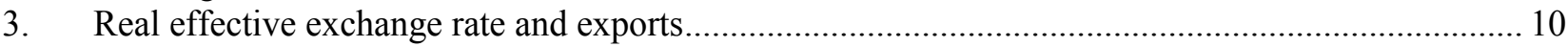

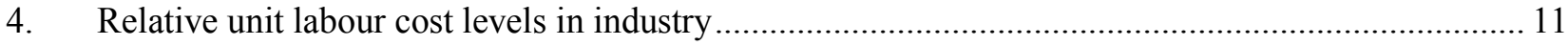

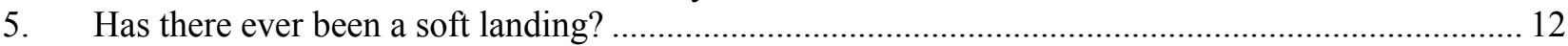

6. Leverage, housing equity withdrawal and the propensity to consume out of housing wealth............ 17

7. Effects of mortgage market completeness .................................................................................... 18

8. Real house price variability and selected explanatory variables................................................ 22

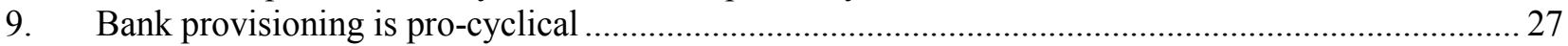

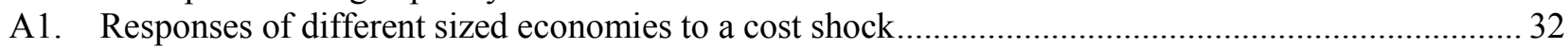

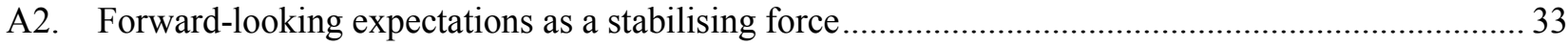

A3. Wealth effects with different expectations mechanisms ............................................................... 34 
ECO/WKP(2007)10 
ECO/WKP(2007)10

\title{
HOUSING MARKETS AND ADJUSTMENT IN MONETARY UNION
}

\author{
By Peter Hoeller and David Rae ${ }^{1}$
}

\section{Introduction}

Monetary union fosters integration by raising price transparency and reducing transactions costs. But it also implies the loss of the sovereign interest rate and exchange rate instruments. This is the main potential cost of joining a monetary union since it becomes more difficult to adjust swiftly to shocks. While price and output adjustment is necessary to absorb shocks, even relatively small inflation differentials that perpetuate over time and become entrenched in expectations can eventually lead to heavy competitiveness losses and painful adjustment. Moreover, sluggish growth for some time could reduce potential output growth due to low investment, loss of skills of the unemployed and withdrawal from the labour market. How large such costs are depends on the frequency and nature of the shocks that hit individual countries. The cost is highest if situations arise where substantially disparate monetary conditions would be called for in different countries due to economic disturbances that have uneven impacts across the area (asymmetric demand shocks). Moreover, the commitments under the Stability and Growth Pact may limit the leeway for fiscal action to smooth the cycle, while labour, product and financial market policies may hinder a speedy adjustment. In the case of demand shocks that affect all countries more or less equally (symmetric shocks), the loss of monetary autonomy implied by EMU is in principle of less concern, because the area-wide policy would tend to deliver monetary conditions that are appropriate for each country. However, this may not always be the case if the transmission mechanism differs across member countries, because then a uniform policy response would not yield uniform effects. Differences in housing markets and their effects on demand are, of course, important in this context.

The paper first highlights factors that limit or increase cyclical divergence. It then reviews one policy area that is important in fostering a speedy adjustment to shocks: the transmission of monetary policy via the housing market, which can be a source of resilience as well as a factor leading to prolonged divergence. As a basic principle, policy should neither hinder adjustment, nor exacerbate the cycle.

The major policy-related findings are:

- Following a positive cost or price shock, the boost to activity coming from lower real interest rates is quickly offset by competitiveness losses in small countries so that the output gap and inflation are back where they should be within a few years. The adjustment is considerably slower in larger countries that are less open to trade. However, asset price bubbles are a cause of concern in the case of small countries as their limited overall weight means that the monetary stance is more likely to be out of line with their cyclical position.

- Backward-looking or extrapolative expectations in the housing market can be highly destabilising. Some element of forward-looking or rational expectations can go a long way to anchoring the housing market. This emphasises the importance of jawboning by policymakers in an attempt to talk down a market that is getting carried away (which is arguably what has happened in the United States in the 1990s boom period).

1. The authors are economists in the OECD's Economics Department. They would like to thank Sebastian Barnes, Pietro Catte, André Christophe, Andrew Dean, Nathalie Girouard, Felix Huefner and Vincent Koen for their useful comments and suggestions. Celia Rutkoski provided first-rate secretarial support. 
- Housing markets are important in the transmission of monetary policy and a high interest rate sensitivity is beneficial as monetary policy is more powerful in damping cyclical fluctuations. However, the characteristics of housing and mortgage markets still differ widely across the euro area, leading to asymmetric behaviour of individual countries. These concern mainly differences in home-ownership rates, financial markets, taxation and supply constraints. Supply constraints and tax incentives to stimulate house ownership can exacerbate volatility in house prices and cyclical divergence.

- Moreover, in the absence of monetary policy and with fiscal policy constrained, it is important to have a financial system that can withstand asset price bubbles. In this context, the pro-cyclicality of bank provisioning is of concern as it could lead to a credit crunch and reinforce a downturn. Prudential supervision across the area has become better co-ordinated, but still remains fragmented.

- Recent OECD Economic Surveys for Denmark, Finland, Ireland, the Netherlands and Spain have pointed to the need to ease supply constraints, to phase out fiscal incentives for housing, to reinforce prudential supervision and to reform social housing policies, which can have implications for migration.

\section{The competitiveness and interest rate channels}

Short-run (benign) price and output adjustment is necessary to absorb shocks. Inflation differentials should be allowed to rectify misalignments in real exchange rates, and the faster they unwind, the lower will be the sacrifice ratio, i.e. the amount of cyclical slack necessary to restore equilibrium in product and labour markets. Hoeller et al. (2002) provide a simple analytical framework to better understand the factors that hinder or help smooth adjustment in monetary union or that are likely to become more prominent with further EU integration: ${ }^{2}$

- Cross-country differences in demand pressures will lead to differences in inflation and labour cost developments, with real interest rates and competitiveness working in opposite directions. In this context it is critical whether real interest rate effects are strong relative to competitiveness effects. A relatively strong competitiveness effect implies rapid adjustment, while a relatively strong real interest rate effect implies a drawn-out adjustment. In a sluggish economy with lower inflation, for instance, rapid gains in competitiveness will boost foreign demand (crowding-in effect), while a strong effect of the higher real interest rate will hold back domestic demand (crowding-out effect).

- Wealth effects can be a double-edged sword. A greater ability to borrow against housing wealth can help smooth consumption by allowing households to borrow their way through a downturn. On the other hand, they can magnify cyclical divergences if households' expectations overshoot into "irrational exuberance". Despite reforms, the mortgage market still differs significantly across countries. In the United States, the United Kingdom and Australia, for instance, the ease and low cost at which housing equity can be withdrawn and mortgage loans refinanced at a lower interest rate has certainly played a role in the resilience of these economies to the negative shocks in recent years. But in Denmark mortgage market liberalisation has helped fuel a substantial and not entirely warranted house price boom that has pushed the economy towards overheating.

2. Deroose et al. (2004) use a similar framework to simulate discretionary budgetary policy, greater labour and product market flexibility and stronger trade integration. See also EC (2006b) for a detailed assessment of the competitiveness and interest rate channels. 
Due to inflation differentials real interest rates have differed a lot across countries. Over the recent cycle, short-term interest rates were low in Ireland, Greece, the Netherlands, Portugal and Spain. But in Germany they were clearly very high, with France, Austria, Belgium and Finland in between. In some smaller economies that experienced a sharp decline in interest rates before entering monetary union the boost was compounded by a steep rise in house prices, especially so in Ireland and Spain. House prices also rose steeply in the Netherlands during the late 1990s and more recently in France, while they declined in Germany (Table 1).

Table 1. Real house prices are decelerating in some markets

\begin{tabular}{|c|c|c|c|c|c|c|c|}
\hline \multicolumn{8}{|c|}{ Per cent annual rate of change } \\
\hline & 1995-2000 & 2001 & 2002 & 2003 & 2004 & 2005 & $2006^{1}$ \\
\hline United States & 2.3 & 5.0 & 5.2 & 4.5 & 7.8 & 9.6 & 7.3 \\
\hline Japan & -2.6 & -3.4 & -3.8 & -5.2 & -6.1 & -4.6 & -4.4 \\
\hline Germany & -1.6 & -1.9 & -3.3 & -2.0 & -3.8 & -1.9 & -2.0 \\
\hline France & 2.1 & 6.0 & 6.2 & 9.4 & 12.6 & 13.2 & 10.9 \\
\hline Italy & -0.9 & 5.7 & 6.8 & 7.3 & 7.5 & 5.2 & 4.4 \\
\hline United Kingdom & 8.2 & 6.8 & 14.6 & 14.2 & 10.4 & 3.4 & 2.3 \\
\hline Canada & 0.0 & 2.0 & 7.7 & 6.5 & 7.5 & 7.6 & 9.1 \\
\hline Australia & 3.5 & 6.5 & 15.3 & 15.0 & 4.1 & -1.1 & 1.5 \\
\hline Denmark & 6.7 & 3.4 & 1.3 & 1.1 & 7.9 & 15.6 & 22.4 \\
\hline Spain & 2.6 & 6.5 & 12.9 & 16.4 & 14.8 & 10.9 & 6.9 \\
\hline Finland & 7.8 & -3.5 & 8.3 & 4.5 & 5.9 & 5.1 & 9.8 \\
\hline Ireland & 17.6 & 4.1 & 5.6 & 11.4 & 9.1 & 9.4 & 11.7 \\
\hline Netherlands & 11.6 & 5.6 & 4.3 & 2.4 & 2.9 & 3.3 & 3.1 \\
\hline Norway & 9.3 & 3.9 & 3.6 & -0.7 & 9.6 & 6.6 & 8.4 \\
\hline New Zealand & 1.7 & -0.8 & 6.6 & 17.3 & 15.2 & 11.1 & 6.7 \\
\hline Sweden & 6.3 & 5.1 & 4.3 & 4.2 & 8.2 & 8.1 & 11.5 \\
\hline Switzerland & -2.5 & 0.9 & 4.0 & 2.3 & 1.5 & -0.1 & 1.8 \\
\hline Euro area ${ }^{2,3}$ & 1.3 & 3.3 & 4.1 & 5.7 & 5.8 & 5.5 & 4.4 \\
\hline Total of above countries ${ }^{3}$ & 1.7 & 3.3 & 4.5 & 4.4 & 5.4 & 5.7 & 4.6 \\
\hline \multicolumn{8}{|c|}{ 1. First half of 2006 relative to first half of 2005 . } \\
\hline \multicolumn{8}{|c|}{$\begin{array}{l}\text { 2. Germany, France, Italy, Spain. Finland, Ireland and the Netherlands. } \\
\text { 3. Using } 2000 \text { GDP weights. }\end{array}$} \\
\hline \multicolumn{8}{|c|}{$\begin{array}{l}\text { Source: Various national sources, see table A.1 in Girouard, N., M. Kennedy, P. van den Noord and C. André, "Recent house price developments: the role of funda- } \\
\text { mentals", OECD Economics Department Working Papers, No. 475, } 2006 \text {. }\end{array}$} \\
\hline
\end{tabular}

To be sure, there have been more factors than interest rates driving house prices. Over long periods of time, by far the most important factor is real per capita income, since higher incomes lead to greater consumption of all goods and services, including housing. Most econometric studies find that the long-run income elasticity of real house prices is between 1 and $2 .{ }^{3}$ Strong income growth has been a key factor behind the house price booms in Ireland, Finland, and Spain (Figure 1). Demographic factors are also important. Population growth, often driven by immigration, ${ }^{4}$ obviously drives up the demand for housing, as does a younger population. Portfolio adjustments have also played a role in some countries, where financial liberalisation combined with a reduction in the interest rate risk premium have led households to increase their borrowing levels closer to international norms. The estimated response of house prices to

3. See Table 3 of Girouard et al. (2006a).

4. In some countries, however, a large proportion of the immigrant inflow has been construction workers themselves. 
interest rates varies substantially across econometric studies, but the average semi-elasticity from the studies reported in Girouard et al. (2006a) is around -3.5, i.e. a drop in real interest rates by one percentage point will raise real house prices by $3.5 \%$ in the long run. This is not a large impact, but the effects of a temporary drop in interest rates can get amplified if expectations start to feed on themselves. The rise in house prices has brought forth an increase in supply, especially in Ireland and Spain (Figure 2), leading to a construction boom that to some extent has generated its own economic momentum. The dynamics of house price developments depends critically on the elasticity of housing supply, which itself depends on incentives of municipalities to release land for building and the speediness of building approvals.

Figure 1. Forces shaping housing demand

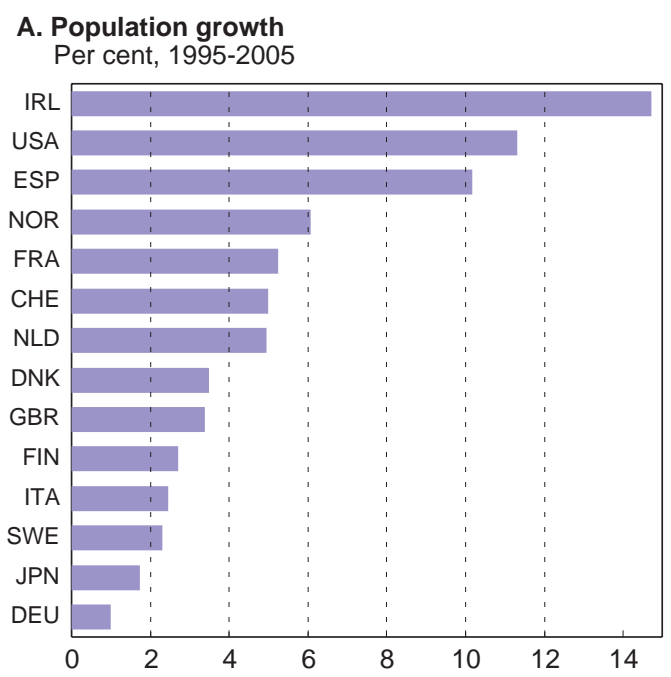

\section{B. Population of household formation age (25-34)} Per cent of adult population, 2005 (1)

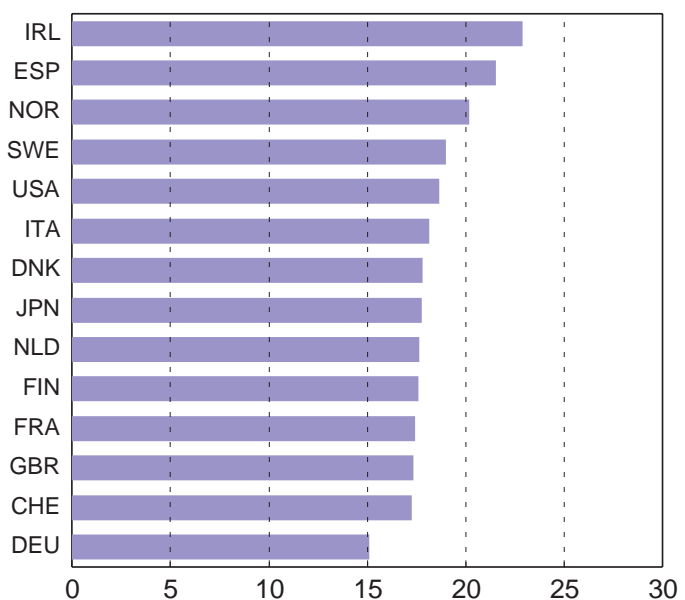

C. Growth in real household disposable income per capita

Percentage points, average 1995-2005

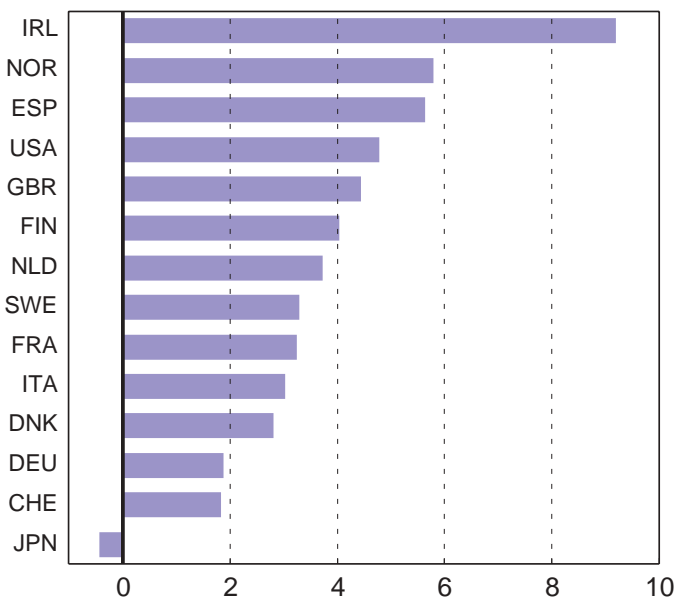

D. Real mortgage interest rates

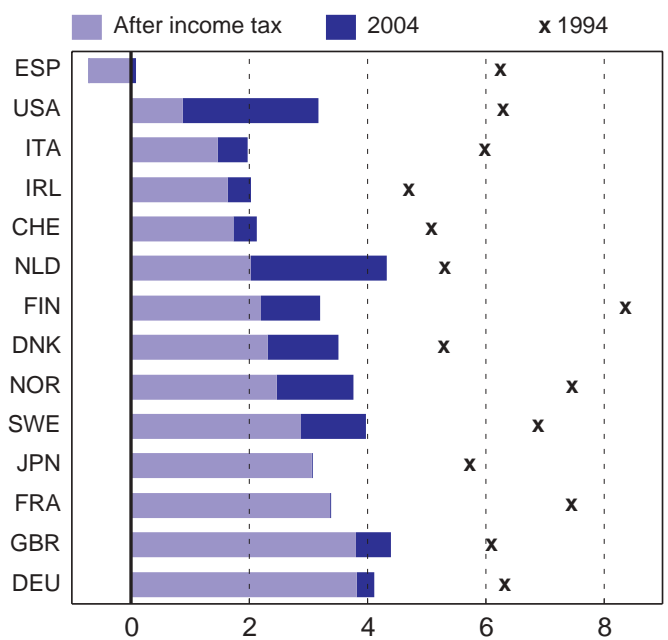

1. The adult population comprises those aged 20 and over.

Source: OECD, Labour Force Statistics (2006), OECD Economic Outlook 79 database and Girouard et al. (2006a), for Panel B. 


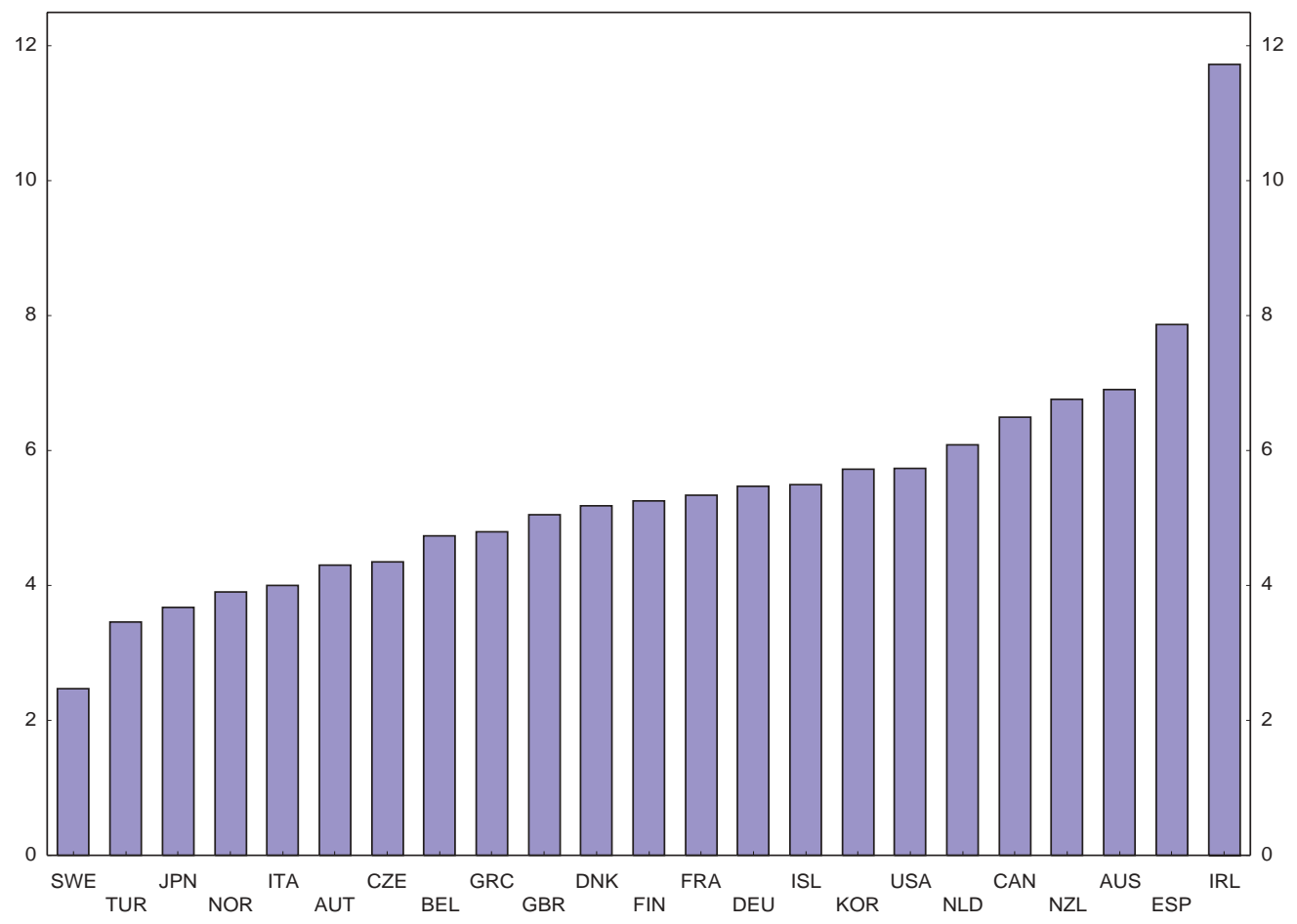

Source: OECD, National Accounts and Economic Outlook 79 database.

Equilibrating forces coming through external demand have helped to some extent (Figure 3), but a key lesson from the early years of monetary union is that this balancing mechanism acts slowly. Fastgrowing economies, and countries where wage gains outstrip productivity, can maintain relatively high inflation for quite some time, putting exporters under pressure. Eventually they will hit a competitiveness wall, and job losses in export industries will put a brake on the more sheltered sectors. But because this feedback is delayed and out of sync with the driving forces of activity, it can lead to boom-bust cycles rather than stable growth. The housing market often plays a central role in magnifying these cycles. The initial impetus for growth in the domestic economy can be a normal convergence process, for example where income and price levels in Spain, Portugal and Greece catch up with the euro area average. However, if price level convergence is not backed up by strong productivity growth, competitiveness will suffer. This is why Ireland has done well on export markets despite substantial real exchange rate appreciation, while Portugal is struggling. Moreover, the convergence process is seldom one where countries land smoothly on their long-run equilibrium path and then settle down to grow at normal rates. Instead, theory ${ }^{5}$ and evidence ${ }^{6}$ show that countries can overshoot. This can be seen in new OECD data on unit labour cost levels (Figure 4). Italy, Portugal and Spain used to have relatively low unit labour costs; Italy and Portugal now overshot considerably, and on current trends Spain will follow suit shortly. It is not just the wealth effect of house prices that contributes to macroeconomic fluctuations; construction cycles can also be destabilising, especially as in the past they have tended to end more with a bang than a whimper (Box 1).

\section{5. $\quad$ See, for example, Lane (2004).}

6. See Sala-i-Martin (1996) and Weber and Beck (2005). 
ECO/WKP(2007)10

Figure 3. Real effective exchange rate and exports

Cumulative change from 1999 to 2005

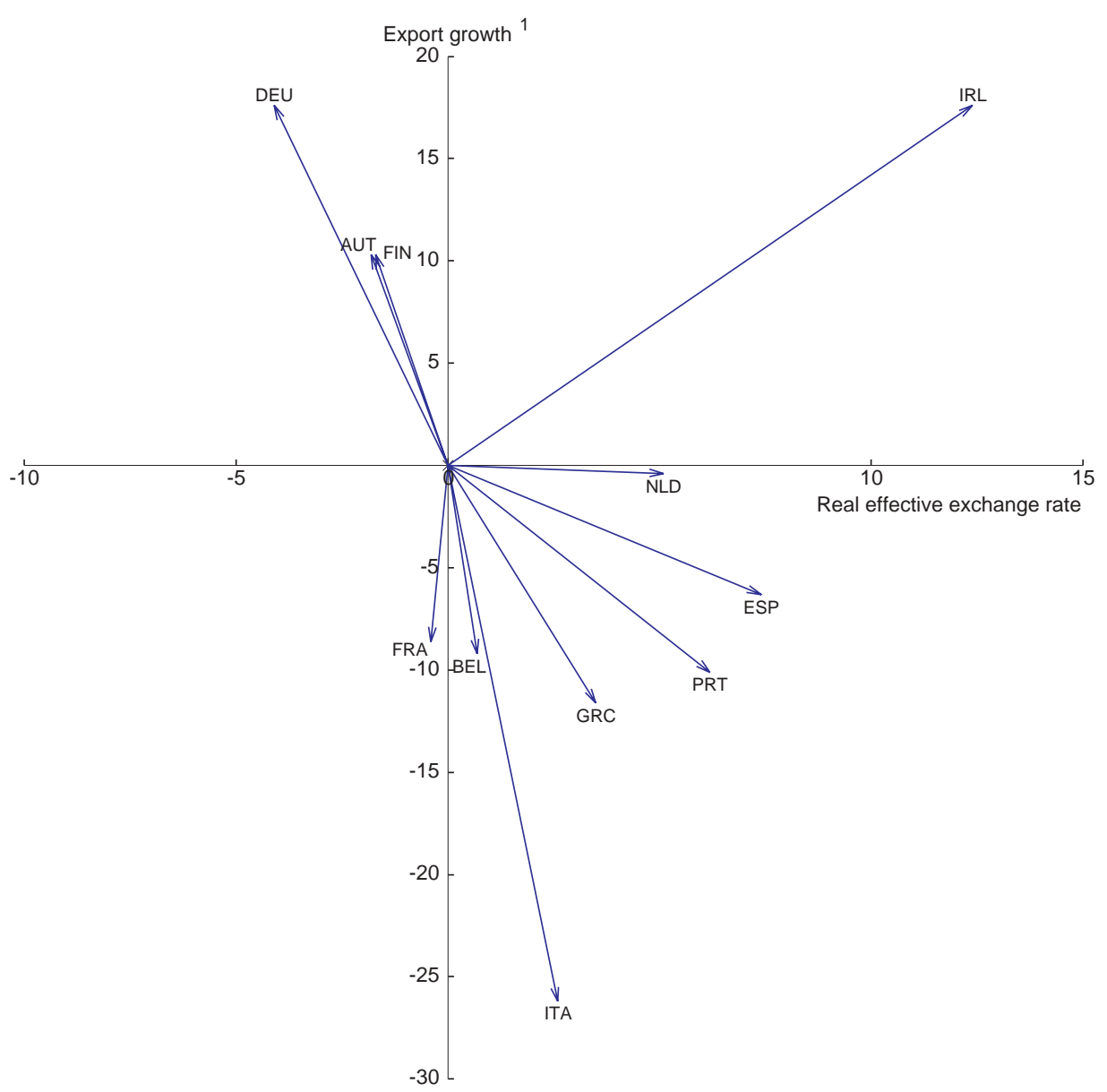

1. Excess over euro area average.

Source: Eurostat and OECD, Economic Outlook database. 
ECO/WKP(2007)10

Figure 4. Relative unit labour cost levels in industry

Euro area $=100$
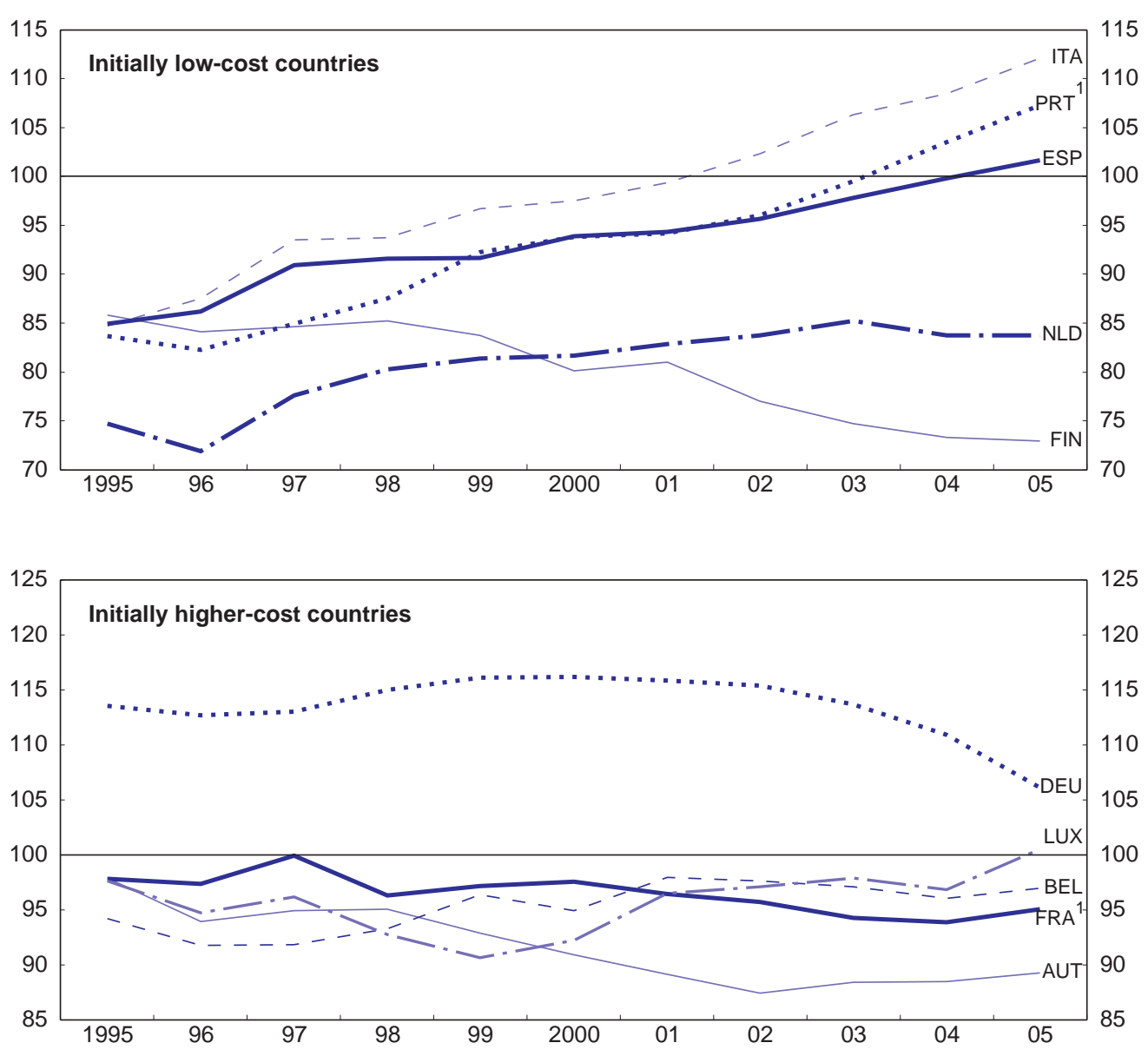

1. Extended using total-economy unit labour costs for Portugal (2003-05) and France (2005).

Source: OECD, Main Economic Indicators - OECD online database and OECD Economic Outlook: Statistics and Projections - online database. 


\section{Box 1. Has there ever been a soft landing?}

Residential investment cycles can be destabilising in their own right. Between 1960 and 2004, 49 residential construction booms have occurred in 23 countries for which data is available (by construction, the latest peak that can be identified is 2002; the analysis here therefore omits the housing booms that are currently underway). In the cycles that have been identified, the average increase in real per capita residential investment from trough to peak is around $40 \%$. The largest occurred in Korea from 1973 to 1978 (where investment rose by 160\%). The trough-to-peak increase has exceeded $50 \%$ in 16 cases.

The downturn that follows is usually rapid. On average in the first year after the peak, $40 \%$ of the increase during the trough to peak upswing is reversed, with another $40 \%$ lost in the second year (Figure 5). Investment stabilises at that level for two years, before beginning to recover about five years after the peak. The spill-over effects to real activity are typically large. GDP growth declines sharply such that the output gap falls by nearly 4 percentage points from peak to trough in the years following the construction downturn. On average, the fiscal balance worsens by $2 \frac{1}{2}$ percentage points of GDP and the unemployment rate rises by $2 \frac{1}{2}$ percentage points. Surprisingly, a tightening of monetary policy is not always the trigger for the end of a construction boom. Of the 34 booms for which there is also data on short-term interest rates, monetary policy tightened before the investment peak only in a little over half of all cases.

Figure 5. Has there ever been a soft landing?
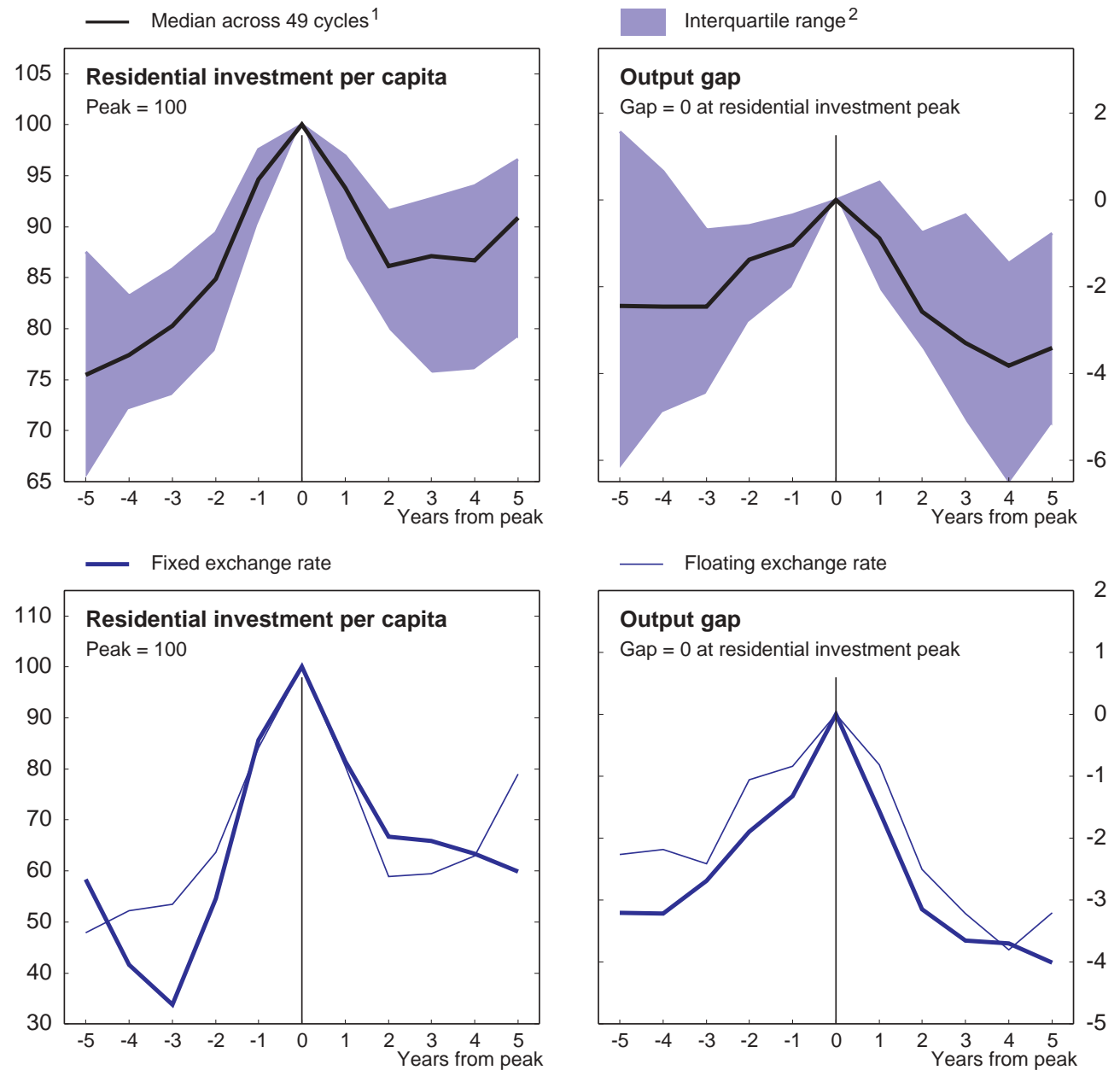

1. In each cycle, real per capita residential investment is scaled so that the peak equals 100 .

2. The shaded area shows the middle two quartiles (i.e. half the countries fall in this range).

Source: OECD (2005), Economic Outlook 79 database. 


\section{Box 1. Has there ever been a soft landing? (cont.)}

There are noticeable differences between countries that had fixed exchange rates at the time and those that were either floating or devalued just after the peak. The size of the boom from trough-to-peak is larger in the fixed exchange rate case and the subsequent slump is longer - the trough of the investment cycle occurs two years after the peak when monetary policy is able to respond, but in the fixed exchange rate case investment is still falling after five years. Some real world examples include Sweden and Finland in the late 1980s and early 1990s, where their downturns would have been even more severe if they had not devalued their currencies.

How common are soft landings? If a soft landing is defined as a relatively small reduction in the investment rate, they are not especially common. There have been only four cases where the decline in per capita residential investment has been smaller than one third of the increase that occurred during the boom years (these are the Netherlands after 1978, Belgium after 1990, the United Kingdom after 1998 and Finland after 2000). Soft landings are more common if they are defined as gradual declines, i.e. where it takes at least three years to hit the trough. There have been around 20 of these. But all were comparatively deep declines. If a soft landing is defined as something that is both mild and gradual, there has not been a single case out of the 49 boom-bust cycles.

Ahearne et al. (2005) conducted a similar exercise except that they looked at house price booms rather than construction cycles. They find that house prices are strongly pro-cyclical, and a recession typically follows a downturn in real house prices. Residential investment normally turns down about a year before house prices.

Source: Rae and van den Noord (2006).

\section{Model simulations of the competitiveness and interest rate channels}

These points are illustrated in more concrete terms with the help of model simulations. The model is described in detail in Annex A. It can be thought of as a stripped-down version of the type of macroeconometric model commonly used by central banks. On the other hand, the housing channel is in some respects richer, and incorporates more modelling options than conventional models.

The conflict between the interest rate and competitiveness channels is illustrated in Figure A1 in Annex A. Two types of economies are compared: an open economy with a high trade exposure, such as Ireland, and a more closed economy, such as France. Each country faces the same positive price or cost shock. The initial jump in inflation has two impacts. The most important is a worsening in competitiveness that reduces exports and boosts imports. This obviously has a larger impact on the more open economy, which is why in the first two years output growth falls by considerably more than in the more closed economy. The second effect is a reduction in real interest rates. This provides an offsetting boost to business investment. It has a negligible initial impact on housing investment because with forward-looking house price expectations, people realise that any rise in house prices will be short-lived. The main difference between the relatively open and closed economies is how quickly the competitiveness channel drives inflation back to $2 \%$. In the open economy, the adjustment is largely complete after a few years whereas the cycles are much more protracted in the economy less exposed to trade because swings in inflation generate real interest rate effects that offset the comparatively weak trade channel. When they work at loggerheads, it takes longer for equilibrium to be restored. The key conclusion here is that a stronger competitiveness channel can create a bigger initial impact for this type of shock, but in general the economy will return to equilibrium more quickly.

The annex also looks at how outcomes are affected by the expectations formation process and the strength of the wealth effect. Briefly, backward-looking or extrapolative expectations in the housing market can be highly destabilising as temporary shocks are magnified and create large and long-lasting housing market bubbles that in turn lead to substantial swings in economic activity and inflation. The simulation with more weight on forward-looking or rational expectations shows cyclical responses that are considerably more damped. Secondly, a strong wealth effect can lead to faster and smoother adjustment to equilibrium when housing market expectations are semi-rational (or forward-looking to some degree), but when expectations are extrapolative the economy would be better off with a smaller wealth effect. 


\section{Other factors}

We will not dwell in detail on the other factors that shape adjustment (see OECD, 2006a, for a more complete discussion). To summarise the main points, deep integration helps by giving greater opportunities for risk sharing across the monetary union. Flexible labour and product markets also help, but most euro area countries are not well-placed in this respect. Cournède et al. (2005) for instance, show that when output is below potential, inflation falls by less in the euro area than in most other OECD countries, partly because of implicit pricing contracts and strategic interactions among firms. Nominal and real wage rigidities are affected by factors such as employment protection legislation and union coverage (EC, 2005). Duval (2007) finds that output gaps are more persistent where labour market and product market regulations are stringent, while high levels of household mortgage debt - which are more often found in deregulated mortgage markets - appear to speed up adjustment. The same factors can also magnify the initial impact of a shock, but Drew et al. (2004) show that from a welfare point of view the economy would be better off if it were flexible (delivering a short, sharp shock rather than a shallower but longdrawn-out adjustment) unless society puts a great deal of weight on inflation stabilisation relative to output stabilisation. In principle, labour mobility can act as a safety valve but in the European context it is unlikely to play an important role in the foreseeable future except perhaps in isolated cases such as Ireland and Spain. The only tool left is fiscal policy, but the need for fiscal consolidation rules fiscal action out in many countries.

Going forward, deeper integration in the European Union should boost trade integration and capital market linkages. Trade intensity and capital market linkages tend to be much larger among regions in a country than across countries. This means that there is less home bias, there are stronger capital market linkages and there is thus more risk sharing.

The European Union has, of course, aimed at deep integration via the single market, thus boosting trade and capital market linkages within the Union. So far, it has been fairly successful in implementing the single market for goods. Integration in other sectors has, on the other hand, still quite some way to go. Concerning financial services, which were further liberalised by the Financial Services Action Plan in recent years, progress towards better integration has been uneven across market segments, with retail banking and mortgage markets being among the least well integrated areas. While market segmentation within the euro area is likely to be smaller than across the countries outside the Union, deep integration has still not been achieved across a variety of important market segments. A hard push to lower market segmentation would especially benefit the large euro area countries, both by reducing cyclical divergence, as it would raise the effectiveness of the competitiveness channel, and by leading to a more homogenous transmission mechanism.

\section{The monetary transmission mechanism differs}

Monetary policy affects output and inflation in many ways. The speed and strength of the monetary transmission mechanism can depend on the flexibility of wages and prices, exposure to trade outside the euro area, the size of equity holdings, whether equity ownership is spread widely across the population and whether it is tied up in pension funds, the stock of foreign assets and liabilities, the extent of relationship banking, corporate and household leverage rates, the size and diversification of banks, the structure of the economy (whether it is service-intensive, for example), the extent of competition in banking and mortgage markets, regulations governing mortgages and consumer credit, and so on. In a sense, therefore, every country has a unique transmission mechanism, being strong in some areas but weak in others. This is why it is difficult to generalise about different monetary responses in, say, the large continental European countries compared with the smaller euro area members. Moreover, the transmission mechanism will change over time within an individual country. For example, the response to a rise in interest rates or the 
exchange rate in Finland or Sweden today would be radically different to 20 years ago when financial and corporate balance sheets were stretched to the limit. Thus, it may not be surprising that while the economic literature does find differences in the overall strength of the transmission mechanism across euro area members, the results do not point to systematic differences and instead depend heavily on the methods used and on which particular channel is being focussed on. ${ }^{7}$ Nevertheless, there are some fairly robust conclusions concerning the housing channel. Some of these are discussed below.

\section{The housing market can be a source of resilience}

Housing markets differ considerably across euro area countries and across the OECD, largely reflecting the extent of liberalisation of the mortgage market, tax regimes and the extent to which house price changes feed through into residential construction. The feed-through can be small if planning restrictions are tight, even though higher house prices could strongly affect consumption via wealth effects. Housing markets are important in the transmission of monetary policy and a high interest sensitivity is beneficial as it implies that monetary policy is more powerful in damping cyclical fluctuations overall in the euro area. Some housing and mortgage market differences are illustrated in Table 2.

The strong transmission of monetary policy via the housing market channel is one of the major mechanisms that have helped in the United Kingdom to keep growth close to potential during the downswing in the early 2000s. It has one of the most liberalised mortgage markets. Loan-to-value ratios are typically lower in continental Europe and transactions costs are higher. The latter are about $2 \%$ of the purchase price in the United Kingdom, but much higher in Germany, Italy and in France. In the large continental Europe countries, the lower degree of liberalisation and lower level of transactions due to the higher transactions costs implies less mortgage equity withdrawal and fewer opportunities for consumption smoothing for liquidity-constrained households. On the other hand, it also implies a lower volatility of house prices. By contrast, cycles in owner-occupied housing markets in some of the smaller euro area countries have produced swings in household wealth that in turn exacerbated the cross-country variation in economic activity.

Changes in house prices and private consumption are correlated in most countries, but to widely varying degrees. Housing wealth effects are strongest in the US, UK, Canada, the Netherlands and Australia and they are small in France, Germany and Italy. Consumption functions show a similar pattern (Catte et al., 2004): the marginal long-run propensity to consume out of housing wealth is between 0.05 and 0.08 (between 5 and 8 cents in the dollar/euro) for the first group of countries, but negligible in Italy and insignificant in France and Germany (Table 3). These cross-country patterns are broadly confirmed in a range of other studies, although not surprisingly different studies do throw up occasional country-specific anomalies. ${ }^{8}$ Taken as a group, however, they deliver a relatively consistent message.

7. The most comprehensive review is the summary of studies undertaken by the Eurosystem's Monetary Transmission Network (Angeloni et al., 2004). Giuliodori (2005) finds that in those countries with more competitive mortgage markets and more efficient housing systems, house prices play an important role in the transmission of an interest rate shock to household consumer spending. The effect is very strong in the United Kingdom and still considerable in Sweden, Finland, Spain and the Netherlands.

8. See Kennedy and Andersen (1994), Henley and Morley (2001), Girouard and Blondal (2001), Iacoviello (2000) and HM Treasury (2003). 
Table 2. Housing and mortgage market characteristics

\begin{tabular}{lcccccc}
\hline & $\begin{array}{c}\text { Residential } \\
\text { mortgage debt } \\
\text { (\% of } \\
\text { disposable } \\
\text { income, } 2003)^{1}\end{array}$ & $\begin{array}{c}\text { Typical loan- } \\
\text { to-value } \\
\text { ratios of new } \\
\text { loans } \\
(\%)\end{array}$ & $\begin{array}{c}\text { Typical loan } \\
\text { term } \\
\text { (years) }\end{array}$ & $\begin{array}{c}\text { Variable } \\
\text { interest rates } \\
(\% \text { of new } \\
\text { loans, 2005) }\end{array}$ & $\begin{array}{c}\text { Securitisation } \\
\text { of mortgages }\end{array}$ & $\begin{array}{c}\text { Home } \\
\text { ownership } \\
\text { rate } \\
(\%, 2002)^{2}\end{array}$ \\
\hline Australia & 120 & $90-100$ & 25 & 84 & Yes & 70 \\
Austria & $\ldots$ & $\ldots$ & $20-30$ & $\ldots$ & $\ldots$ & 56 \\
Canada & 77 & $70-80$ & 25 & 29 & Yes & 66 \\
Denmark & 188 & 80 & 30 & 30 & Yes & 51 \\
Finland & 71 & $75-80$ & $15-18$ & 93 & Limited & 58 \\
France & 40 & 80 & 15 & 32 & Limited & 55 \\
Germany & 83 & $70-80$ & $25-30$ & 16 & Limited & 42 \\
Ireland & 106 & $70-100$ & 20 & 85 & Limited & 77 \\
Italy & 20 & 50 & 15 & 78 & No & 80 \\
Japan & 58 & 80 & $25-30$ & 22 & No & 60 \\
Netherlands & 208 & 87 & 30 & 36 & Yes & 53 \\
New Zealand & 129 & $\ldots$ & $\ldots$ & 33 & $\ldots$ & 65 \\
Norway & 24 & 70 & $15-20$ & $\ldots$ & No & 77 \\
Portugal & 33 & $\ldots$ & 15 & 95 & $\ldots$ & 64 \\
Spain & 67 & $\ldots$ & 15 & 93 & Yes & 85 \\
Sweden & 98 & $80-90$ & $<30$ & 50 & Limited & 61 \\
United Kingdom & 105 & 75 & 25 & 35 & Yes & 69 \\
United States & 78 & 80 & 30 & 35 & Yes & 68 \\
\hline
\end{tabular}

1. 2002 for Norway and Portugal, 2005 estimate for Ireland.

2. Or latest year available.

Source: OECD (2004, 2005, 2006), OECD Economic Outlook, Nos. 75, 78 and 80, Paris.

Table 3. Short-term and long-term impact of financial and housing wealth on consumption

Estimated short-term and long-term marginal propensities to consume out of financial and housing wealth

\begin{tabular}{lcccc}
\hline & \multicolumn{2}{c}{ Short-term } & & \multicolumn{2}{c}{ Long-term } \\
& Housing & Financial & Housing & Financial \\
\hline Australia & 0.02 & $\ldots$ & 0.07 & 0.03 \\
Canada & 0.03 & 0.03 & 0.06 & 0.04 \\
France & $\ldots$ & $\ldots$ & $\ldots$ & 0.02 \\
Germany & $\ldots$ & 0.01 & $\ldots$ & 0.02 \\
Italy & $\ldots$ & 0.01 & 0.01 & 0.01 \\
Japan & 0.01 & $\ldots$ & 0.01 & 0.07 \\
Netherlands & 0.02 & $\ldots$ & 0.08 & 0.06 \\
Spain & 0.01 & $\ldots$ & 0.02 & 0.02 \\
United Kingdom & 0.08 & 0.03 & 0.07 & 0.04 \\
United States & $\ldots$ & 0.02 & 0.05 & 0.03 \\
\hline
\end{tabular}

Source: Catte et al. (2004), "Housing Markets, Wealth and the Business Cycle", OECD Economics Department Working Papers, No. 394 . 
The size of the long-run marginal propensity to consume out of housing wealth is positively correlated with mortgage debt ratios across countries. Mortgage markets seem pivotal in translating house price swings into spending responses (Figure 6, panel A). Mortgage debt ratios show large cross-country differences, with ratios being particularly high in Denmark, the Netherlands and the UK and low in France and Italy (Table 2).

Figure 6. Leverage, housing equity withdrawal and the propensity to consume ${ }^{1}$ out of housing wealth
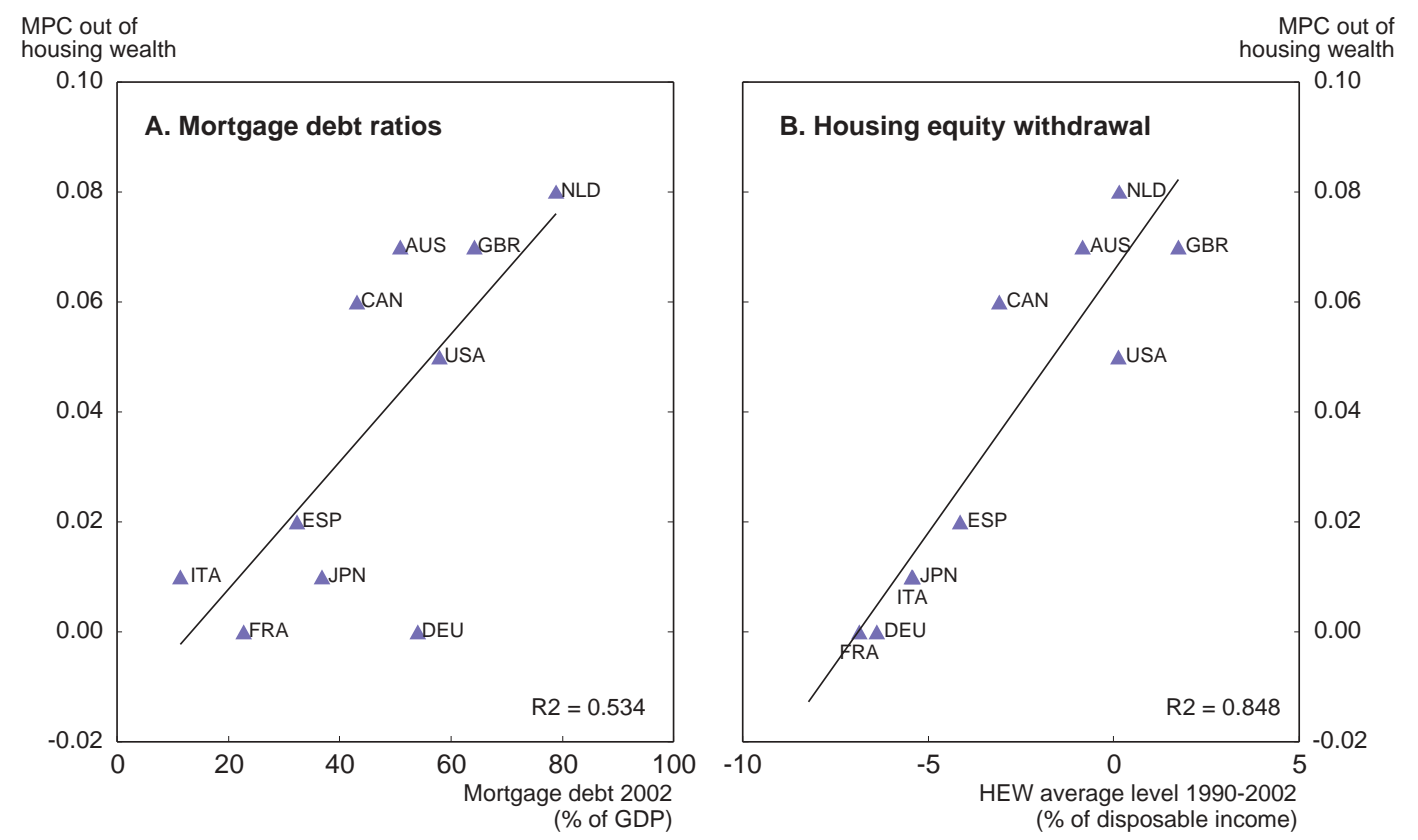

1. MPC stands for marginal propensity to consume and HEW for housing equity withdrawal.

Source: European Mortgage Federation; US Federal Reserve Board; Japan Statistics; UK Office for National Statistics; Bank of Canada; Bank of France; Statistics Canada; Bank of the Netherlands; Bank of Spain; ECB; Reserve Bank of Australia and OECD.

The influence of the housing market on consumption depends on the extent to which housing wealth can be accessed and, in particular, how easy it is for homeowners to borrow against housing wealth through mortgage equity withdrawal, defined as the increment to the mortgage debt less the amount used for residential construction. Indeed, the size of mortgage equity withdrawal is closely correlated with the impact of housing wealth on consumption (Figure 6, panel B). The strong correlation suggests that it is liquidity constraints that matter in the countries that show a low correlation.

What explains the large country differences? Major factors are financial market characteristics, housing transactions costs and exemptions from capital gains taxes and a high rate of owner-occupancy (Catte et al., 2004).

Financial market characteristics can be summarised in an index of market completeness. Less regulated and more competitive markets offer a greater variety of mortgage products, serve a broader range of borrowers and apply lower mortgage interest spreads. They also provide second mortgages and mortgage equity release products. Indeed, for the few countries for which the completeness index exists, there is a strong correlation between the consumption sensitivity to changes in real house prices and this index (Figure 7, panel A). There is also a close correlation with mortgage equity withdrawal (Figure 7, panel B). 


\section{Figure 7. Effects of mortgage market completeness ${ }^{1}$}
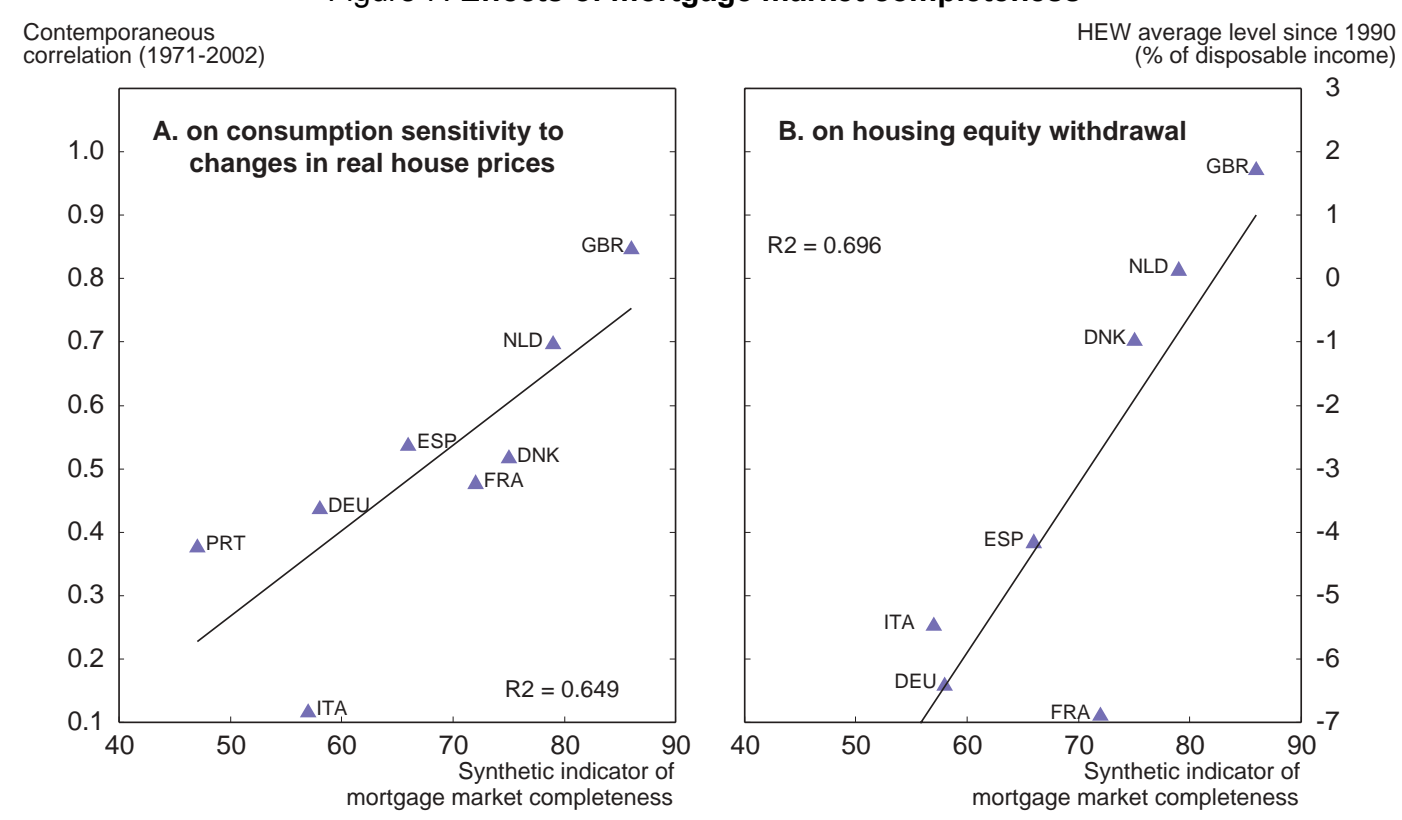

1. HEW stands for housing equity withdrawal. The synthetic indicator of mortgage market completeness is presented in Table 5 of Catte et al. (2004).

Source: Mercer, Oliver and Wyman (2003); US Federal Reserve Board; Japan Statistics; UK Office for National Statistics; Bank of Canada; Bank of France; Statistics Canada; Bank of the Netherlands; Bank of Spain; ECB; Reserve Bank of Australia and Catte et al. (2004), "Housing Markets, Wealth and the Business Cycle", OECD Economics Department Working Papers, No. 394.

The composition of mortgages as between fixed and variable rates is also of crucial importance. In Germany, for instance, rates are typically at a fixed rate for 10 years and it is very difficult to refinance. In Finland, Ireland, Italy, Portugal and Spain, most loans are variable rate loans and interest rate changes feed through quickly into monthly service payments. In the United States, where most loans are fixed rate, penalty free prepayment options are common, as mortgage lending is largely funded through callable mortgage-backed securities (Green and Wachter, 2005). The distinction between variable and fixed rates has become blurred by product innovation: mortgages can also have an initial period with fixed rates, where the interest rate can be fixed for another period after the initial fixed period, or move to a variable rate, while for mortgages with a capped rate, the variable interest rate paid by the borrower cannot rise above an agreed capped rate. And there are several more complex products (EMF, 2006), which makes the classification into variable and fixed rate mortgages difficult. For instance, Denmark has a share of nearly $50 \%$ of variable (adjustable) rate loans on the national definition, but only $30 \%$ on the definition by the European Mortgage Federation, which is used in Table 2. Moreover, the share of variable and fixed rate loans in new loans can change quickly with a change in the yield curve. For instance, the United Kingdom, which tended to be a country with a high share of variable loans has seen this share plummeting in recent years as the yield curve has flattened.

Two key indicators of the mortgage market's ability to provide access to financing are typical or maximum loan to value ratios and mortgage terms. Both are strongly correlated with the size of mortgage markets (Table 2). Maximum ratios are above $100 \%$ in the Netherlands and the UK and particularly low in Italy. The Italian case is striking as it has one of the highest home ownership rates and one of the smallest mortgage markets (Box 2). Concerning mortgage terms, equity withdrawal is easy in most Englishspeaking countries, the Netherlands and several Nordic countries. They are not widely marketed or not offered in France, Belgium and in southern European countries. Such differences partly reflect the legal protection of collateral, which seems weak in France, Belgium, Italy and Portugal, which have long legal procedures for repossessions. 


\section{Box 2. Why has the Italian mortgage market been so small?}

Italy has one of the highest rates of home ownership and one of the smallest mortgage markets. Even more striking is the fact that households' ease in obtaining credit has differed a lot across local markets. Several studies have concluded that this has not been due to a low propensity of households to incur debt, but rather to a less developed credit supply. Liberalisation of financial markets since the mid-1980s has led to the opening of many branches, a shift to the universal banking model and entry of foreign banks and has raised competition and brought down interest rate spreads. Despite rapid growth in mortgage lending the market is still among the smallest in international comparison.

Casolaro et al. (2005) argue that inadequate formal and informal loan contract enforcement was a main factor, which has held back the development of the mortgage market. Time to decision in a trial and recovery of funds following a default has been very long, while social capital - the set of relationships that tie people together in a community - was also weak on average. Moreover, there was considerable variation across the Italian regions and low social capital and weak legal enforcement have tended to go hand in hand.

There are, of course, also other factors at play. For instance, information between borrowers and lenders is asymmetric. In most English-speaking countries specialised credit reference agencies report the credit histories of loan applicants and creditors share information. In some European countries, including Italy, such agencies are still in their infancy and information exchange on defaults and arrears is limited, so that information is potentially more asymmetric. In the presence of severe information problems, lenders protect themselves with larger down payments (Chiuri and Jappelli, 2001).

Such credit market imperfections affect the age profile of home ownership, obliging young people to save and postpone a home purchase until later in life. Overcoming them, will shift the ownership profile towards younger cohorts and prompt a temporary spurt in demand for home mortgages. Indeed, the indebtedness of young cohorts has become relatively high and there may be a cohort effect at play with young, higher debt cohorts replacing older low-debt cohorts over time (Girouard et al., 2006b).

Further liberalisation and better integration of mortgage markets and lower transactions costs across the euro area countries would be beneficial from the point of view of economic efficiency. It would also strengthen the effectiveness of monetary policy, while at the same time reducing asymmetries in the transmission channel between countries.

\section{Tax incentives, tight zoning and pro-cyclical bank provisioning tend to reinforce the cycle}

Cycles in owner-occupied housing markets can also produce swings in household wealth that in turn exacerbate the cross-country variation in economic activity. To the extent that housing cycles are asymmetric, i.e. not synchronised and/or very different in intensity across the monetary union, they also tend to intensify cyclical swings. The house price cycle stems from the relatively inelastic supply of housing which results in strong movements in prices, which can be amplified or damped by tax policy.

\section{Tax incentives}

The main purpose of any tax is to raise revenues, but the tax system is also used to promote various economic and social objectives. This is done by tax exemptions, preferential tax rates, and special reliefs. Taken together these elements undermine tax neutrality and create distortions.

One issue in assessing housing taxation and tax neutrality is that housing is a special good: it can be either considered as an investment or as a consumption good. As housing provides a flow of services consumed by people, it should be taxed so that the costs of owner occupation and renting are equal. The tax advantage of homeowners is that they do often not pay taxes on the services (imputed rental income) provided by housing, while they are allowed to deduct the mortgage interest payments from income tax. According to the tax neutrality principle, the imputed rental income should be taxed, but homeowners should be allowed to deduct their mortgage interest payments and operating costs from this income. On the other hand, as an investment good housing should be taxed such that it would not distort incentives to 
invest in different assets. In this case, the additional tax advantage of investing in housing relative to other forms of investment is that capital gains from housing are often exempt from taxation. In practice, tax systems often violate the tax neutrality principle between different forms of investment and housing tenure (Table 4). Home ownership is often promoted by the deductibility of mortgage interest payments and the non-taxation of imputed rental income and capital gains.

Tax incentives that stimulate house ownership can exacerbate volatility in house prices. A tax system that contains generous incentives for house ownership not only results in a higher steady-state level of house prices (and an associated misallocation of resources), but may also result in greater volatility of house prices, as the tax incentive can increase the slope of the demand curve. The tax breaks for owner-occupied housing could act as a destabilising force, to some extent offsetting the automatic stabilising properties that are normally attributed to income taxation.

Van den Noord (2005) estimates the real financing cost of housing and the tax wedge between the market interest rate and the financing cost of housing investment. The real cost of financing is generally lowest in the smaller euro area economies, but is high in Germany. These tax incentives had been introduced to boost home ownership and to offset the high real cost of financing prior to the introduction of the common currency. Theory suggests that price variability of owner-occupied homes would be largest in countries where the tax breaks for owner-occupied housing are largest. Regressing the marginal effective tax wedges on owner-occupied housing in euro area countries on the variability of house prices (gauged by the standard deviation of the house price index) confirms this (Figure 8, panel C).

An additional type of housing taxation is that on property values. This tax often raises revenue to finance local services provided by the municipalities, but may also accrue to central government. It can also be a means to tax gains from the increase in the value of property due to the changes in the zoning of land. Furthermore, a property tax may be considered as a tax on location. The property tax differs from the tax on imputed rental income as it does not involve taxation of the service income provided by housing and hence does not necessarily affect the tax neutrality between rental housing and owner occupation. 
Table 4. Taxation of residential property

\begin{tabular}{|c|c|c|c|c|c|}
\hline \multirow[b]{3}{*}{ Austria } & \multirow{2}{*}{$\begin{array}{l}\text { Imputed } \\
\text { rental } \\
\text { income } \\
\text { taxed }\end{array}$} & \multicolumn{2}{|c|}{ Tax relief on mortgages } & \multirow{2}{*}{$\begin{array}{c}\text { Capital gains on } \\
\text { housing assets } \\
\text { taxable }\end{array}$} & \multirow{2}{*}{ Inheritance tax } \\
\hline & & Interest & $\begin{array}{l}\text { Principal } \\
\text { repayments }\end{array}$ & & \\
\hline & $\mathrm{N}$ & $\begin{array}{l}\text { Y } \\
\text { (up to ceiling) }\end{array}$ & $\mathrm{N}$ & $\mathrm{Y}$ & $\bar{Y}$ \\
\hline Belgium & $\begin{array}{l}\text { Y } \\
\text { (with fixed } \\
\text { deduction) }\end{array}$ & (within limit) & $\begin{array}{l}\text { Y } \\
\text { (within limit) }\end{array}$ & $\begin{array}{l}\text { Y } \\
\text { (if sold < } 5 \text { years) } \\
\text { POOD are exempt }\end{array}$ & $\mathrm{Y}$ \\
\hline Canada & $\mathrm{N}$ & $\mathrm{N}$ & $\mathrm{N}$ & $\begin{array}{l}\text { Y } \\
\text { (on } 50 \% \text { of gains) } \\
\text { POOD are exempt }\end{array}$ & $\begin{array}{l}\mathrm{N} \\
\text { (but subject to } \\
\text { capital gains tax) }\end{array}$ \\
\hline Denmark & $\mathrm{N}$ & Y & n.a. & $\begin{array}{l}\text { Y } \\
\text { POOD are exempt }\end{array}$ & $\mathrm{Y}$ \\
\hline Germany & $\mathrm{N}$ & $\mathrm{N}$ & $\mathrm{N}$ & $\begin{array}{l}\text { Y } \\
\text { (if sold <10 years) } \\
\text { POOD are exempt }\end{array}$ & $\begin{array}{l}\text { Y } \\
\text { (lower than for } \\
\text { financial assets) }\end{array}$ \\
\hline Finland & $\mathrm{N}$ & $\begin{array}{l}\text { Y } \\
\text { (up to a } \\
\text { ceiling) }\end{array}$ & n.a. & $\begin{array}{l}\text { Y } \\
\text { POOD exempt if } \\
\text { sold }>2 \text { years }\end{array}$ & $\mathrm{Y}$ \\
\hline France & $\mathrm{N}$ & $\mathrm{N}$ & $\mathrm{N}$ & $\begin{array}{l}\text { Y } \\
\text { POOD are exempt }\end{array}$ & $\mathrm{Y}$ \\
\hline Ireland & $\mathrm{N}$ & Y & $\mathrm{N}$ & $\begin{array}{l}\text { Y } \\
\text { POOD are exempt }\end{array}$ & $\mathrm{Y}$ \\
\hline Italy & $\begin{array}{l}\mathrm{N} \\
\text { (for POOD) }\end{array}$ & $\begin{array}{l}\text { Y } \\
\text { (for POOD) }\end{array}$ & $\mathrm{N}$ & $\begin{array}{l}Y \\
\text { (50\% for POOD) }\end{array}$ & Y (until 2001) \\
\hline Netherlands & $\mathrm{Y}$ & $\mathrm{Y}$ & $\mathrm{N}$ & $\mathrm{N}$ & $\begin{array}{l}\text { Y } \\
\text { (above tax free } \\
\text { threshold) }\end{array}$ \\
\hline Norway & $\mathrm{Y}$ & $\begin{array}{l}\text { Partly } \\
\text { (as other } \\
\text { interest } \\
\text { expenses) }\end{array}$ & $\mathrm{N}$ & $\mathrm{Y}$ & $\mathrm{Y}$ \\
\hline Spain & $\begin{array}{l}\mathrm{N} \\
\text { (for POOD) }\end{array}$ & $Y^{\prime}$ & Y & $\begin{array}{l}\text { Y } \\
\text { (exempt if } \\
\text { reinvested) }\end{array}$ & Y \\
\hline Sweden & $\mathrm{Y}$ & $\mathrm{Y}$ & $\mathrm{N}$ & $\begin{array}{l}\text { Y } \\
\text { (exempt if } \\
\text { reinvested) }\end{array}$ & $\mathrm{N}$ \\
\hline United Kingdom & $\mathrm{N}$ & $\mathrm{N}$ & $\mathrm{N}$ & $\begin{array}{l}\text { Y } \\
\text { POOD are exempt }\end{array}$ & $\mathrm{Y}$ \\
\hline United States & $\mathrm{N}$ & $\begin{array}{l}\text { Y } \\
\text { (up to ceiling) }\end{array}$ & $\mathrm{N}$ & $\begin{array}{l}\text { Y (until 2002) } \\
\text { (deduction for } \\
\text { POOD if held }> \\
2 \text { years) }\end{array}$ & $\begin{array}{l}\text { Y } \\
\text { (to be phased } \\
\text { out) }\end{array}$ \\
\hline
\end{tabular}

Note: $P O O D=$ principal owner-occupied dwelling.

Source: Catte, P. et al. (2004), "Housing Markets, Wealth and the Business Cycle", OECD Economics Department Working Papers, No. 394; Baunkjoer, C.F. (2004), "Housing Taxation", Housing and Housing Policy in Nordic Countries, M. Lujanen (ed.), Nordic Council of Ministers. 
Figure 8. Real house price variability and selected explanatory variables ${ }^{1}$
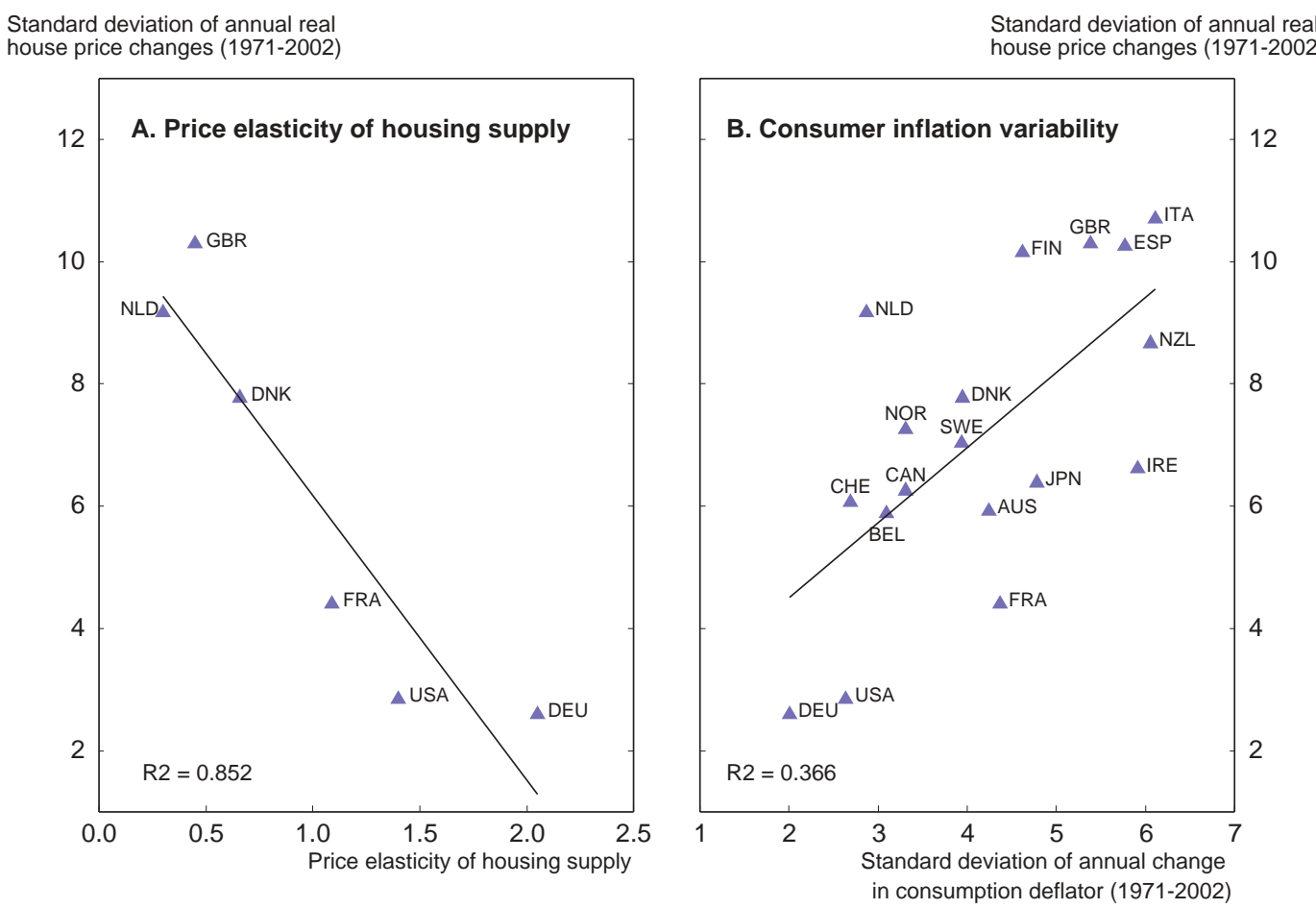

Standard deviation of annual real

house price changes (1971-2002)
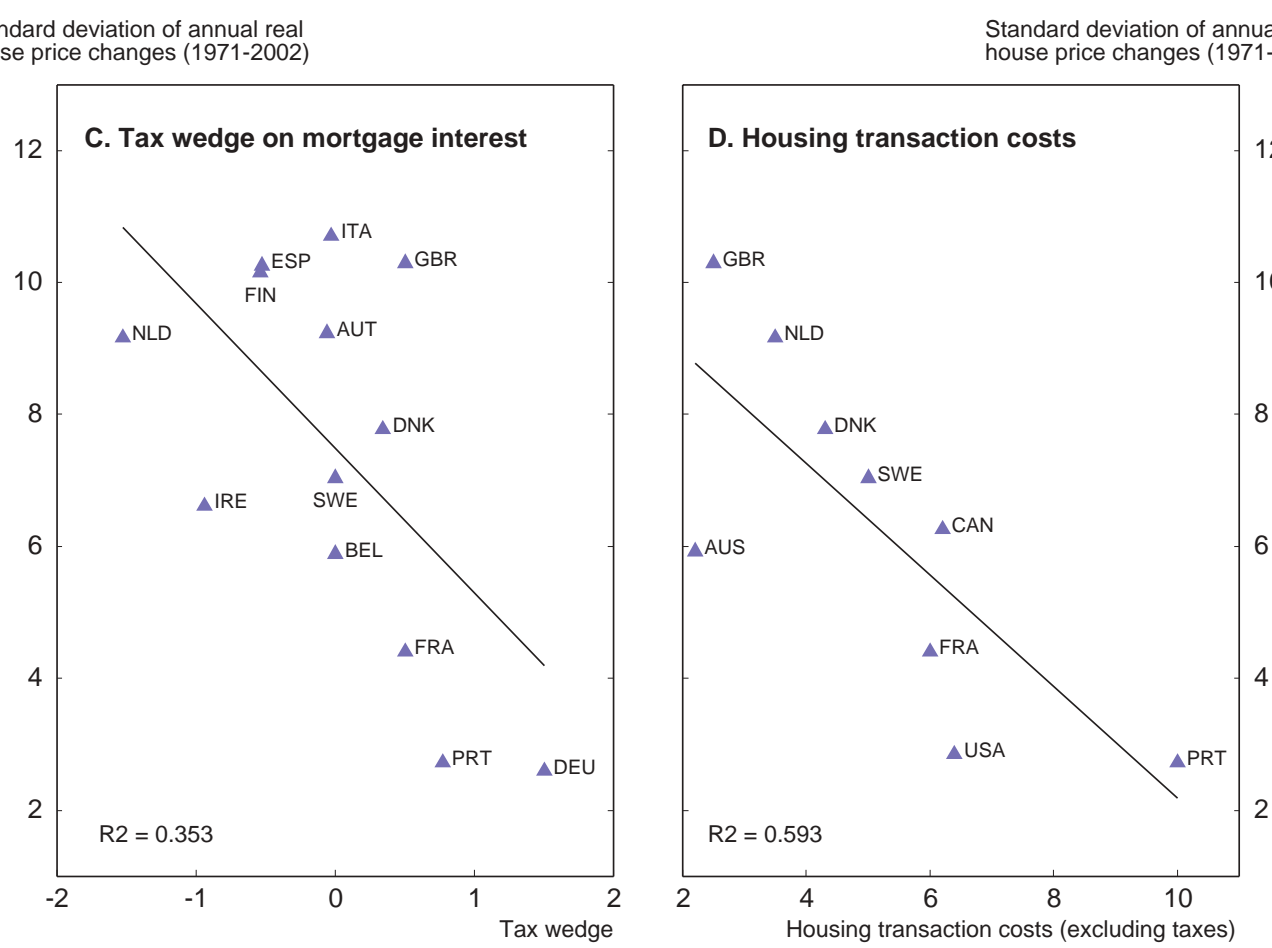

1. In panel $\mathrm{C}$, the tax wedge is defined as the difference between the after-tax and the pre-tax real interest rate on mortgage loans. It also incorporates the effect of property taxes. Thus, a low or negative tax wedge indicates a more favourable tax treatment of mortgage interest.

Source: BIS and Quotable Value New Zealand for house price data; the Economist for data on housing transaction costs; Swank et al. (2002) for estimates of price elasticities of housing supply; Van den Noord (2005) for tax wedges on mortgage interest and OECD for data on consumer inflation variability. 
Maclennan et al. (1998) and Muellbauer (2005) argue that the taxation of residential property would help in dampening house price cycles since higher house prices have an immediate effect on tax payments and thus on households' income. Moreover, if households extrapolate house price rises into the future they will also anticipate the greater tax burden. This will lead to more cautious spending and portfolio decisions. But for the stabilisation mechanism to work effectively, tax rates need to be high enough and property tax needs to be linked to current or recent house price developments throughout the house price cycle. However, the property tax take tends to be low in the euro area countries at typically well below $1 \%$ of GDP (France being an exception with $2 \%$ of GDP). This is because tax rates are low and in many countries property values are updated only with a long lag. ${ }^{9}$ Taxation of residential property is close to $3 \%$ of GDP in Canada, the United Kingdom and the United States.

\section{Zoning regulations}

The variability of house prices is likely to be higher if the supply of housing is price-inelastic and if the demand for housing is subject to large shocks. There is evidence that supply rigidities are indeed important (Figure 8, panel A). The housing stock is given in the short run, while its long-run elasticity with respect to relative price changes is likely to depend mainly on the natural or policy-induced scarcity of urban land. For example, several studies (Swank et al., 2002 and EC, 2006a) have found that in the United Kingdom tough local zoning regulations and a slow authorisation process are among the reasons for the rigidity of housing supply, and an important factor for both the trend rise of house prices and their high variability. The elasticity is also very low in the Netherlands, while it is relatively high in France, Germany or the United States.

While aggregate supply elasticities can shed some light on supply constraints, they say nothing about the underlying mechanisms. Economic analysis and evidence in this area is sparse for the euro area countries,${ }^{10}$ but the OECD country reviews shed light on the underlying mechanisms:

- In Finland, land prices have risen much faster than construction costs, an astonishing feature because Finland is sparsely populated and land is abandoned around the metropolitan areas (Vartia, 2006). This is partly explained by the slowness of the planning process, which allows for multiple possibilities to appeal over decisions on local plans and building permits. More importantly perhaps, municipalities have a disincentive to allocate sufficient land for construction purposes, because they are responsible to provide costly infrastructure and also pay for schools, children day care, health care and other services for new residents. Against this, the property tax rate on residential buildings is capped at $0.5 \%$ and only provided $2 \%$ of total municipal revenues in 2004.

- In Denmark, zoning regulations are tough and cumbersome and administrative procedures slow, and migration will increase net expenses of a municipality in the short run (Erlandsen et al., 2006). Moreover, in the Copenhagen area, the weak supply response is also related to insufficient infrastructure capacity, which raises commuting time and makes the development of new areas outside the capital less attractive.

- In the Netherlands, tough zoning regulations, especially in rural areas, are a major barrier to increased land supply, while building regulations are cumbersome and have grown in complexity. Moreover, the use of public enquiry procedures has increased, which delays the issuing of building permits (OECD, 2004).

9. Linking property taxation to actual price developments is politically sensitive. Denmark, for instance, has frozen valuations and Sweden is currently planning to abolish the tax.

10. Much more is available for the United Kingdom (see for instance, Barker, 2006) and the United States (see for instance, Glaeser et al., 2005 and Saks, 2005). 
- Housing supply has reacted strongly in Spain to the surge in house prices, with the share of residential construction rising to $9 \%$ of GDP in 2005, nearly double the EU average. Local governments, which control the supply of building land, face conflicting incentives. Municipalities are entitled to $10 \%$ of the rezoned land and thus have an interest to keep land prices high. On the other hand, they benefit directly from rezoning and have thus an incentive to approve new developments. On balance, the overall effect has increased the price of land, which is reinforced by the length and complexity of local planning procedures to build the required infrastructure (OECD, 2006c).

\section{Prudential supervision issues}

Housing bubbles can be very costly. In Finland, the bursting of the housing bubble in the early 1990s led to a decline of GDP by more than $10 \%$ and in Sweden by nearly $5 \%$, even though they eased monetary policy a lot and fiscal policy absorbed part of the shock (Eschenbach and Schuknecht, 2002). ${ }^{11}$ The question arises of who is in charge of avoiding asset price bubbles and what can be done to avoid a heavy impact. There are arguments in favour of monetary policy to at least lean against the wind, if house prices rise strongly economy-wide, while others have argued that pricking a bubble is futile and potentially costly (Box 3). This clearly leaves a heavy responsibility for the institutions that supervise the financial system. In the absence of a monetary policy at the national level and with fiscal policy constrained, it is important to have a financial system in place that is robust in the face of asset market bubbles.

\section{Box 3. What should central banks do about house price booms?}

The question of how central banks should respond to asset price booms remains hotly debated. Leaving aside the most extreme views (that there is no such thing as a bubble or that asset prices should form part of the price index and be targeted directly), the issue is whether central bankers should try to stop asset price bubbles developing even if there does not seem to be any threat to price stability over the medium term.

On one side are those who argue that central banks should not try to prick bubbles but should mop up afterwards (Posen, 2006). The US Federal Reserve is in this camp. First of all, bubbles are hard to recognise. It is difficult to know whether an asset price or credit boom is justified by economic fundamentals such as a pickup in productivity growth or whether it reflects irrational exuberance by investors. Second, policymakers couldn't prick a bubble even if they were sure there was one. If a bubble is being driven by irrational expectations of higher returns, an extra 50 basis points on interest rates is unlikely to make much difference and the sort of increase in interest rates that would be required would risk driving the economy into recession. The implicit view is that the reaction to interest rate increases is discontinuous: no reaction to moderate increases, but financial collapse and recession following large increases. Third, the optimal policy is to cut interest rates aggressively after the bubble bursts. Policy should be asymmetric because the financial transmission mechanism through which asset prices affect economic activity is asymmetric: in a downswing, credit constraints and falling collateral values act as financial multipliers. Fourth, bubbles are harmful only when the financial system is fragile, but a problem of under-capitalised banks or poor supervision should be dealt with directly.

On the other side are those who believe that central banks should lean against asset price booms, even if it means that inflation under-shoots its target for a while (Roubini, 2006). By doing so, policymakers are taking out insurance against a costly boom-bust cycle, and tighter monetary policy is the insurance premium that must be paid. The main arguments are as follows. First, the problem of being unsure whether there is a bubble is no different in principle from the sort of uncertainty that policymakers face all the time. An optimal policy rule would still put weight on asset prices, although the weight would be less the greater is the uncertainty. Second, they dispute there being a

11. In Finland, most of the credit losses came from corporate loans, while credit losses from housing loans were small. But households reacted to excess indebtedness and declining collateral values by accelerating the pay-back of loans, resulting in a rise in the saving ratio. This reduced domestic demand and increased the number of bankruptcies in the non-tradeable sector and thereby the credit losses of banks. The total costs of the banking crisis are estimated at 8 to $10 \%$ of GDP. The government provided the banks with around $€ 16$ billion. The net cost to the government was half of this amount (OECD, 2006b). 
discontinuous reaction to interest rate increases. In their view there are several examples where central banks have contributed to deflating asset price booms. Third, the type of boom can make a difference. Real estate busts are more costly than equity busts because bank-based financial systems, which are more exposed to real estate, tend to incur larger losses than market-based systems. A fourth argument is sometimes put forward - that an asymmetric policy creates a moral hazard problem for investors (the "Greenspan put", in which the central bank implicitly underwrites the market), but few policymakers take this argument seriously.

\section{Are current arrangements for cross-border supervision sufficient?}

The IMF-World Bank Financial Sector Assessment Programmes found that the supervisory systems in the euro area (as well as EU) countries are of a higher and more even quality than in comparable countries (IMF, 2006). However, there are still gaps between member country practices and the international standards and Assessment Programmes highlighted the need to meet new challenges, in particular those relating to cross-sector and cross-border financial integration. At the same time, IMF (2006) also noted that the Assessment Programmes usually devote only limited resources to analysing cross-border issues, because they focus on individual countries. Cross-border issues have so far not come to the fore, because even in the countries where the housing market has turned, such as the Netherlands and Portugal, the effects on the financial system were benign. However, the current set-up could be tested in the future.

Supervisory structures vary considerably across the euro area. The dominant forms of supervision at the national level are through separate entities for bank, insurance and securities supervision or through an integrated supervisor for all industries. In recent years, there was a trend towards adopting the single supervisor model (ECB, 2006a). In some countries the central bank is responsible for supervision, in others an independent agency, while in a few, both are involved. Cross-border issues in the euro area are not tackled via a centralised supervisory authority, but via co-ordination and co-operation between the supervisory authorities. The ESCB is currently only peripherally involved, though it is charged with contributing "to the smooth conduct of policies pursued by competent national authorities relating to the prudential supervision of credit institutions and the stability of the financial system" (Art. 105(5)). ${ }^{12}$ It also fulfils a consultative and advisory role in the rule making process. Concerning its tasks, the Banking Supervisory Committee assists the ESCB in the fulfilment of its tasks, by analysing matters of a macroprudential nature, reviewing developments in the banking and financial systems and promoting cooperation and exchange of information between central banks and banking supervisory authorities. On the other hand, the national central banks undertake the lender of last resort function and provide emergency liquidity assistance to financial institutions. They, and the national deposit insurance or national budget, bear the eventual cost of intervention. However, if liquidity assistance has consequences for monetary policy, the ECB will become involved.

The single market in banking is based on the harmonisation of a minimum set of uniform banking regulations across the Union, mutual recognition of other regulations and policies and home country control in supervision. ${ }^{13}$ Banks can thus establish branches in other countries, without having to undergo a review by the regulators of the host countries. If a bank establishes a separately chartered subsidiary, the host country is responsible for supervision, though the supervision of the consolidated entity remains the responsibility of the home country. Co-operation among supervisors, which concerns information exchange, supervisory and crisis management procedures about cross-border activities is achieved by 2003 and 2005 multilateral Memoranda of Understanding (MoU) between the supervisors, finance ministries

12. Art 105(6) suggests that the ECB could be assigned supervisory powers in the future, except for insurance. There would thus be no need to reform the Treaty in this respect.

13. The following is mainly based on ECB (2006b), Gulde and Wolf (2005) and Eisenbeis and Kaufman (2006). 
and central banks in the EU. The $2005 \mathrm{MoU}$ also includes arrangements for the development of contingency plans for the management of crisis situations, along with stress-testing and simulation exercises. The home country approach and rising financial market integration should lead to regulatory competition, which in turn should lead to a less regulated and homogenous market place. However, it could also lead to problems and conflicts, if systematically important banks run into trouble.

First, agency problems can arise, as the incentives of regulators, deposit insurance providers and failure resolution entity are likely to be aligned with the residents of the regulators' home or host country, rather than with the interests of all customers of the financial institution. Risks may be shifted across the border as well as associated costs to taxpayers as regulators attempt to ingratiate themselves with constituent banks. Second, information problems arise, as foreign branches do not have meaningful balance sheets separate from the bank as a whole. This becomes critical, when foreign branches have a high share of the domestic market, as the host country is responsible for financial stability and the lender of last resort function. Third, home country regulators may take insufficient account of externalities that a failure, and the way it is resolved, may affect the host country. Finally, the Memoranda of Understanding are only agreements and can not be enforced under law. Regulators could thus take actions to benefit their own country's residents and institutions.

The EU arrangements for financial crisis management have been subject to a comprehensive review and may, of course, provide a coherent and flexible strategy for safeguarding financial stability. But the current fragmentation, information and incentive problems could raise systemic risks, the costs of financial instability and hinder the speedy resolution of failed banks.

\section{Bank provisioning tends to be pro-cyclical}

In the absence of a monetary policy and with fiscal policy constrained, it is important to have a financial system in place that is robust in the face of asset market bubbles. If banks mis-assess risks during the business cycle, underestimating them in good times and overestimating them in bad times, the potential for credit and asset market booms and busts is increased, thereby destabilising the economy.

Over recent years, significant advances have been made in the measurement of credit risks. However, macroeconomic considerations still play only a small role in most approaches (Lowe, 2002). And there is a risk that changes to the Basle II Capital Accord may lead to an even greater financial amplification of the business cycle. ${ }^{14}$ Under the current Basel Accord, minimum capital requirements on a given portfolio are fixed and they typically become binding through a fall in a bank's capital following credit losses. Under the proposed system of risk-based capital, requirements would become binding through an increase in minimum requirements as loans migrate to higher risk classes (Jokipii and Milne, 2006). Just when banks are most likely to record losses, the minimum capital requirements could themselves increase. From a macro-prudential perspective, the time dimension and the endogeneity of risk is important. Cushions should be built up in upswings to be relied upon in rough times. This would enhance an institution's ability to weather deteriorating economic conditions when access to external financing becomes more costly and constrained. Moreover, by leaning against the wind, it would reduce the amplitude of the financial cycle, limiting the risk of financial distress in the first place (Borio, 2003).

14. The pro-cyclicality could also diminish, as the awareness about the implications of an unduly pro-cyclical risk assessment has risen both among market participants and supervisors. Moreover, greater disclosure may become less tolerant and suspicious about risk assessments that change a lot over time and lead to substantial upgrades in good times. 
Figure 9, which shows GDP growth and bank provisioning, highlights a pronounced pro-cyclical pattern for the euro area. Dobson and Hufbauer (2001) observe the following on forward loss provisioning: "Banks are often reluctant to make adequate provision for their loan losses, and bank regulators are often hesitant about pushing banks to recognize losses before it becomes plain that borrowers are in trouble. No bank loan officer wants to admit she made a mistake, and few supervisors want to cry "fire" when there is only smoke. As a consequence, published loan-loss provisions usually lag the eruption of a financial crisis. Hence, when the crisis strikes, banks typically have inadequate cushions of equity plus reserves to absorb the loss." They also observe that forward provisioning will require a change in tax laws so that loan-loss deductions can be taken in excess of historical experience. Current practice tends to permit deductions only for recognised problem loans.

Figure 9. Bank provisioning is pro-cyclical

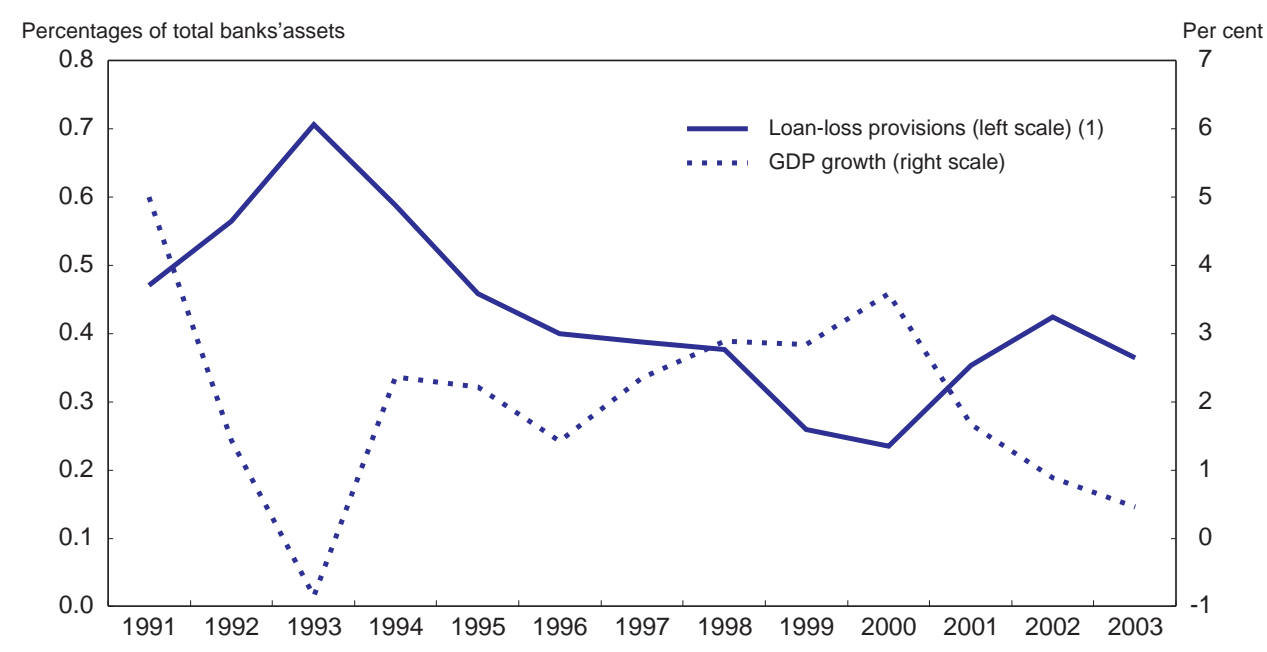

1. Loan-loss provisions data for 2003 have been inferred from data of the largest 50 banks for the first half of 2003.

Source: Bankscope, Eurostat, OECD and ECB calculations.

Empirical work for Spain (Ayuso, 2004), Norway (Lindqvist, 2004) and for a large sample of European countries (Bikker and Metzemacher, 2003 and Jokipii and Milne, 2006) tends to confirm this behaviour. These studies relate loan loss provisions or the capital buffer to indicators of the economic cycle, like GDP growth, the output gap or the unemployment rate, while controlling for various bank specific conditions, like loan growth, earnings and equity or capital ratios. They tend to find a negative relationship between the cycle and provisioning, though Jokipii and Milne (2006) also find a significant positive relationship for the countries that joined the Union in 2004 and for co-operative and small banks.

Spain has adopted a novel approach, by issuing a new loan-loss regulation in 2000. It obliges all deposit institutions to determine provisions based on default rates over the business cycle, rather than at a point in time. This forces banks to provide for bad loans during economic expansions by more than in the past, and thus avoids increased provisioning during recessions. While the new rule does not increase the overall level of provisions over the whole business cycle, it makes risk assessment more complex and requires a major effort of risk management by credit institutions. These have established their own risk management mechanisms to adapt to the new rule, while a standard management framework has been approved for those banks that do not have the technical capability to develop their own model (Fernández de Lis et al., 2001). The adoption of international accounting standards by the Union in 2004 obliged the Bank of Spain to change its provisioning framework, though it still contains a strong macro-prudential focus (Bank of Spain, 2005). 


\section{What did the OECD recommend in its surveys?}

The Danish, Dutch, Finnish, Irish and Spanish Economic Surveys included chapters or sections on housing markets in recent years. ${ }^{15}$ Despite the rapid rise in prices in Denmark, Ireland and Spain, econometric work found some, but only limited overvaluation of house prices, because fundamentals, like demographics or income gains, also rose rapidly, and income and interest rate elasticities are high. On the other hand, the supply elasticity is very low in the Netherlands.

The recommendations are actually very similar:

- Improve supply conditions by improving zoning laws (Finland, the Netherlands and Spain) and remove financial obstacles to new land developments (Denmark).

- $\quad$ Phase out tax breaks (Denmark, Finland, Ireland, the Netherlands and Spain).

- $\quad$ Raise property tax to fund local infrastructure (Denmark, Finland and Ireland).

- Encourage banks to be sufficiently prudent in their lending and loan-loss provisioning (Ireland and Spain already in place). Phase out a loan guarantee scheme in Finland. Remove legal barriers that block improved risk assessment (Denmark).

- Improve social housing policy (Denmark, Finland, Ireland, the Netherlands and Spain). Use vouchers or tenure-neutral housing benefits. Migration effect is of concern in Finland, the Netherlands and Spain.

- Remove rent controls (Denmark).

15. Also recent UK surveys discussed housing market issues and the latest Economic Survey of Sweden includes an in-depth chapter on housing markets. Denmark, though outside the euro area, is included in this section, because its monetary policy shadows that of the European Central Bank. 
ECO/WKP(2007)10

\section{ANNEX A. A MODEL OF A SMALL COUNTRY IN A MONETARY UNION}

This section describes the stylised model used for the simulations reported in the body of the paper. It has a relatively standard form, and can be thought of as a stripped-down conventional macro-econometric model such as FRB-US, the Bank of Canada's QPM or the various country blocks of the Eurosystem's ESCB model. For simplicity, much of the richness of these models has been removed in order to concentrate on the salient features of the housing channel for monetary policy. On the other hand, the housing channel is in some respects richer, and incorporates more modelling options, than conventional models.

The model has two types of households - hand-to-mouth consumers who consume out of their current disposable income, and forward-looking consumers who consume out of their wealth. Equilibrium consumption $\left(c^{*}\right)$ is a weighted average of the two types of households, where $y d$ is real disposable income and $W$ is real housing wealth (non-housing wealth is ignored as it will not play an important role in the discussion below). In all the equations below, variables denoted by lower-case letters are in logs:

$c^{*}=\alpha y d+(1-\alpha)[\beta W]+$ const.

The baseline version of the model assumes a strong wealth effect and few hand-to-mouth consumers by setting $\alpha=0.1$. The parameter $\beta$ is chosen to give a long-run marginal propensity to consume out of wealth equal to 0.05 while the constant term ensures that the wealth-to-consumption ratio equals 3 in equilibrium. Actual consumption is modelled by an error correction equation:

$$
\Delta c_{t}=0.1 \Delta c_{t-1}-0.25\left(c-c^{*}\right)_{t-1}+\delta_{1} \Delta y d+\delta_{2} \Delta W_{t}-\delta_{3}\left(r_{t}^{H}-3\right)
$$

In this equation, the short-run income and wealth elasticities can differ from and are typically larger than the long-run elasticities. $r^{H}$ is the real interest rate for households (see below). Consumption also responds to the level of real interest rates (over and above its equilibrium value of $3 \%$ ). This term could equivalently be incorporated within the long-run part, but the distinction is irrelevant in this model where the equilibrium real interest rate is exogenous. In the baseline model, $\delta_{1}=0.1$ and $\delta_{2}=0.04$.

Residential investment, $i^{H}$, is consistent with a Q-theory formulation. It depends negatively on the real interest rate and positively on the ratio of house prices to consumer prices (plus a constant, which is not shown). In the long run, the investment-to-income ratio will be constant:

$$
\Delta i_{t}^{H}=0.3 \Delta i_{t-1}^{H}-0.2\left(i^{H}-y\right)_{t-1}-\chi_{1}\left(r_{t}^{H}-3\right)+0.05\left(p^{H}-p^{C}\right)
$$

Non-residential (other) investment is similar, except it does not include the real house price term and uses the real interest rate faced by firms rather than households:

$$
\Delta i_{t}^{O}=0.3 \Delta i_{t-1}^{O}-0.2\left(i^{O}-y\right)_{t-1}-\chi_{2}\left(r_{t}-3\right)
$$

Exports and imports are modelled as error correction equations, depending on output (with unit elasticity), the real exchange rate and short-run dynamic effects. At a given real exchange rate (rer), exports and imports will be a constant proportion of output in the long run:

$$
\begin{aligned}
& \Delta x_{t}=0.2 \Delta x_{t-1}-0.5(x-y)_{t-1}-0.5 \text { rer }_{t-1}-0.4 \Delta \operatorname{rer}_{t-1} \\
& \Delta m_{t}=0.2 \Delta m_{t-1}-0.5(x-y)_{t-1}-0.5 r e r_{t-1}-0.1 \Delta r e r_{t-1}+0.25 \Delta \log \left(Y_{t-1}+M_{t-1}\right)
\end{aligned}
$$


Employment is modelled as an Okun-type relationship (the employment gap being proportional to the output gap) augmented with a negative feedback from real wages to ensure a constant wage share in equilibrium (consistent with an underlying Cobb-Douglas production technology):

$n_{t}-n_{t}^{*}=0.33\left(y_{t-1}-y_{t-1}^{*}\right)-0.5\left(w-p^{C}-y^{*}\right)_{t-1}$

Consumer price inflation is determined by a Phillips curve, depending on expected inflation and the output gap. Expected inflation is a weighted average of the central bank's inflation target ( $2 \%$ per annum) and past inflation. The coefficient $\varphi_{1}=0.001$, which implies a sacrifice ratio consistent with those of a small economy in the INTERLINK model:

$\Delta p_{t}^{C}=0.5 \Delta p_{t}^{T}+0.5\left(p_{t-1}-p_{t-5}\right) / 4+\phi_{1}\left(y_{t}-y_{t}^{*}\right)$

Wages are determined by a similar equation, and are largely tied to consumer prices but are anchored to some extent by the inflation target. The coefficients assume a significant degree of real wage inertia. The output gap appears, but with a much smaller coefficient than in the consumer price equation, to reflect cyclical bargaining factors. An equilibrium-correction term also appears in order to tie down the level of real wages in the long run, although the adjustment speed is slow:

$$
\Delta w_{t}=0.2 \Delta p_{t}^{T}+0.8\left(p_{t-1}-p_{t-5}\right) / 4+\phi_{1} / 10\left(y_{t}-y_{t}^{*}\right)-0.1\left(w-p^{C}-y^{*}\right)_{t-1}
$$

Firms' inflation expectations, which feed into the business investment equation, are a weighted average of the average inflation rate over the past three years and the inflation target:

$$
\pi_{t}^{e, B}=0.2(2)+0.8\left[100 \log \left(p_{t} / p_{t-12}\right) / 3\right]
$$

The real interest rate faced by firms is equal to the nominal rate (fixed at 5\%) minus expected inflation:

$$
r_{t}=5-\pi_{t}^{e, B}
$$

Expected house price inflation can take several forms. There are two backward looking options, being functions of past house price inflation or consumer price inflation:

$$
\begin{aligned}
& \pi_{t}^{e, H}=100\left(p_{t-1}^{H}-p_{t-13}^{H}\right) / 3 \\
& \pi_{t}^{e, H}=100\left(p_{t-1}^{C}-p_{t-13}^{C}\right) / 3
\end{aligned}
$$

In the forward-looking option, rather than assuming perfect foresight at every point in time, we assume that households form an expectation of the weighted average of actual future house price inflation, where the weights decline geometrically over time. In this way, the infinite future is taken into account but with more weight being given to the near future. This reflects the assumption that people may be more confident in their forecasts over shorter horizons than longer horizons and that they may get the average inflation rate right but are not able to foresee the precise quarter-by-quarter profile. Medium-term expected house price inflation can be written:

$$
\pi_{t}^{e, H}=(1-\lambda) \sum_{i=0}^{\infty} \lambda^{i} E\left[\left(p_{t+i}^{e, H}-p_{t+i-1}^{e, H}\right) \times 400\right]
$$


Shifting this equation forward by one quarter to solve for $\pi_{t+1}^{e, H}$, multiplying by $\lambda$ and subtracting from the above equation gives the third option for expected house price inflation:

$$
\pi_{t}^{e, H}=\lambda \pi_{t+1}^{e, H}+(1-\lambda)\left(p_{t}^{H}-p_{t-1}^{H}\right) \times 400
$$

This procedure is the forward-looking analog to the standard Koyck lag transformation. The advantage from a computational point of view is that all the forward-looking house price terms collapse down to a single one-period-ahead value. Lambda is set at 0.9 , implying a median lead of around five years.

The three different formulations for expectations are nested in a single equation with weights that can vary. The baseline version of the model is purely forward-looking, i.e. a weight of 1 on option (c) and 0 on options (a) and (b).

The real interest rate faced by households, which feeds into the consumption and dwelling investment equations, becomes:

$r_{t}^{H}=5-\pi_{t}^{e, H}$

Actual house prices depend on expected house price inflation as calculated above. It also depends on consumption growth (reflecting a consumption-driven asset price boom), real interest rates and an equilibrium correction term to ensure that real house prices are tied down in the long run.

$$
\Delta p_{t}^{H}=\pi_{t}^{e, H} / 400-0.25\left(p_{t-1}^{H}-p_{t-1}^{C}\right)+0.25 \Delta c_{t}-\chi_{3} r_{t}^{H}
$$

Because this is assumed to be a small economy in the monetary union, nominal interest rates and the nominal exchange rate are fixed exogenously. The only other exogenous variables are government spending, potential employment, potential output and the foreign price level. The model includes standard identities for GDP, the output gap, housing wealth, the real exchange rate (measured in terms of the consumer price index, $p^{C}$ ) etc.

The parameters have been selected so that the model's responses to standard shocks are similar to those of the OECD's INTERLINK model. No attempt has been made to estimate them econometrically as this is a stylised model that deliberately abstracts from many features of the real world in order to focus on the issue at hand, namely the way in which the housing market can propagate shocks in a monetary union.

\section{Illustrative simulations}

\section{The competitiveness and interest rate channels}

The first simulation consists of an asymmetric price or cost shock. The consumer price level is assumed to increase by $1 \%$ in the first quarter of the simulation. Two variants of the model are used: a small open economy, such as Ireland, is compared with a more closed economy such as France. The only difference between the models is the magnitude of trade relative to GDP. In the open economy, baseline exports and imports both equal $40 \%$ of GDP, compared to $15 \%$ in the more closed economy. House price expectations are assumed to be forward-looking, and the wealth effect is "switched on".

The results are shown in Figure A1. The initial jump in inflation has two impacts. The most important is a worsening in competitiveness that reduces exports and boosts imports. This obviously has a larger impact on the more open economy, which is why its output growth falls by considerably more in the first 
two years. The second effect is a reduction in real interest rates. This provides an offsetting boost to business investment. It has a negligible initial impact on dwelling investment because with forwardlooking house price expectations, people realise that any rise in house prices will be short-lived. The main difference between the relatively open and closed economies is how quickly the competitiveness channel drives inflation back to $2 \%$. With a fixed exchange rate, the price level has to end up at baseline in the long run so that the real exchange rate returns to equilibrium, and therefore inflation has to under-shoot the target level for a time. In the more open economy, this adjustment is largely complete after a few years whereas the cycles are much more protracted in the economy less exposed to trade. The main reason why the cycles last so long in this case is that the swings in inflation generate real interest rate effects that offset the comparatively weak trade channel. When they work at loggerheads, it takes longer for equilibrium to be restored. The key conclusion here is that a stronger competitiveness channel can create a bigger initial impact for this type of shock, but in general the economy will return to equilibrium more quickly. ${ }^{16}$

Figure A1. Responses of different sized economies to a cost shock
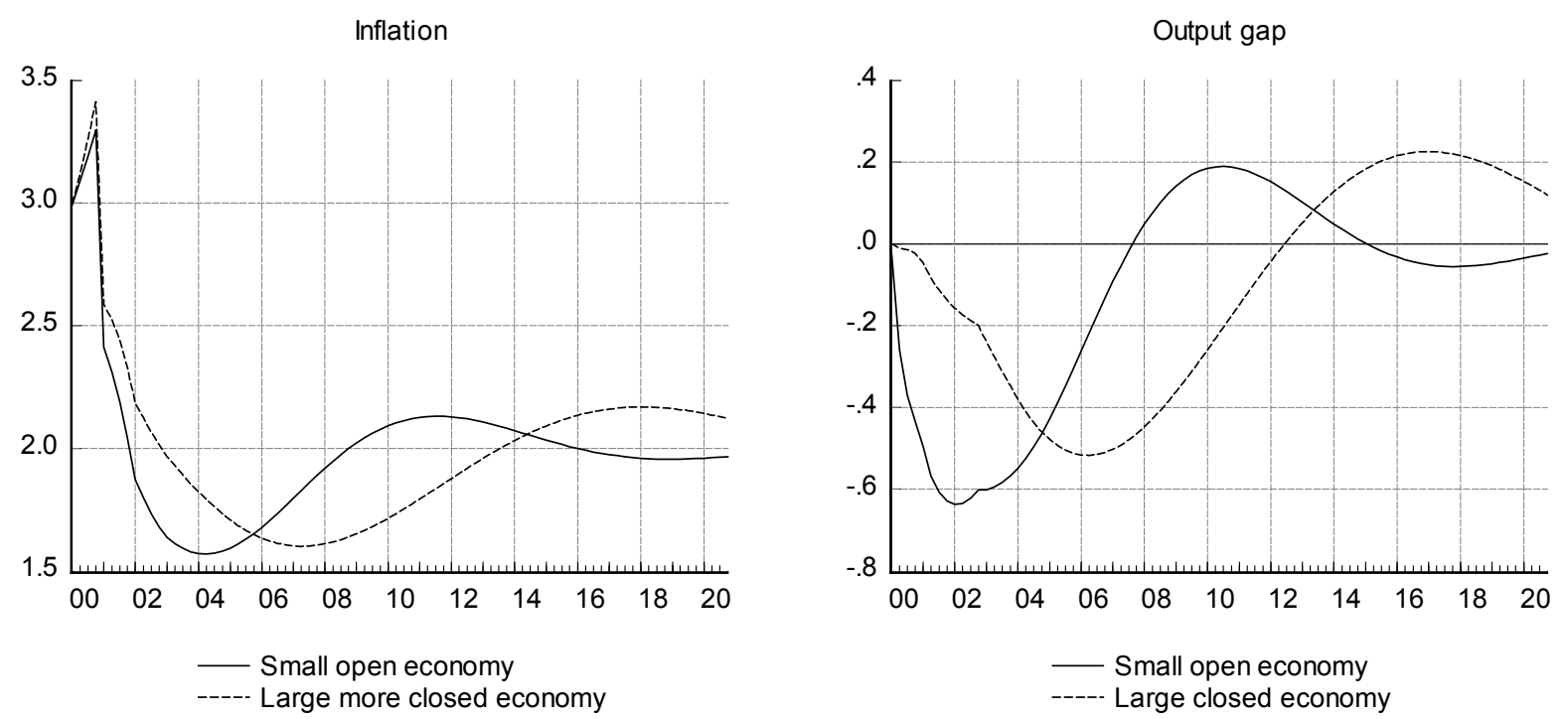

In the large country case, spill-over effects to area wide inflation may not be trivial and could induce a monetary policy easing. However, a decline in French inflation by 0.5 percentage points in the middle years of the simulation would reduce area wide inflation by only 0.125 percentage points, which would be too small to trigger a noticeable monetary policy response.

\section{The role of expectations}

The second simulation consists of a negative demand shock. Consumption growth is reduced in the first four quarters of the simulation so that, if there were no offsetting or feedback effects, consumption would be $5 \%$ lower after the first year. The first version of this simulation assumes that house price expectations are largely forward-looking, as in the previous scenario. The second version has a mixture of backward-looking and forward-looking house price expectations; specifically, a 50:50 weight on options (a) and (c) above. The wealth effect is operating in both cases. As can be seen in Figure A2, the response over the first two years is almost the same. The cycles die down quickly when house price expectations are relatively rational. However, backward-looking expectations tend to amplify the housing channel, leading

16. For a pure demand shock, by contrast, the initial impacts are not much different but the more open economy still comes back to equilibrium faster. 
to larger and longer-lasting swings in activity and inflation. For example, falling house prices lead to higher real interest rates in the housing market, further reducing residential investment, consumption and house prices themselves. It also cuts consumption through the wealth channel, which in turn is a further drag on consumer prices and house prices. Both channels feed on themselves, magnifying and prolonging the initial disturbance. The magnitude of these cycles will be larger when the feedback from the competitiveness channel is weaker.

Figure A2. Forward-looking expectations as a stabilising force
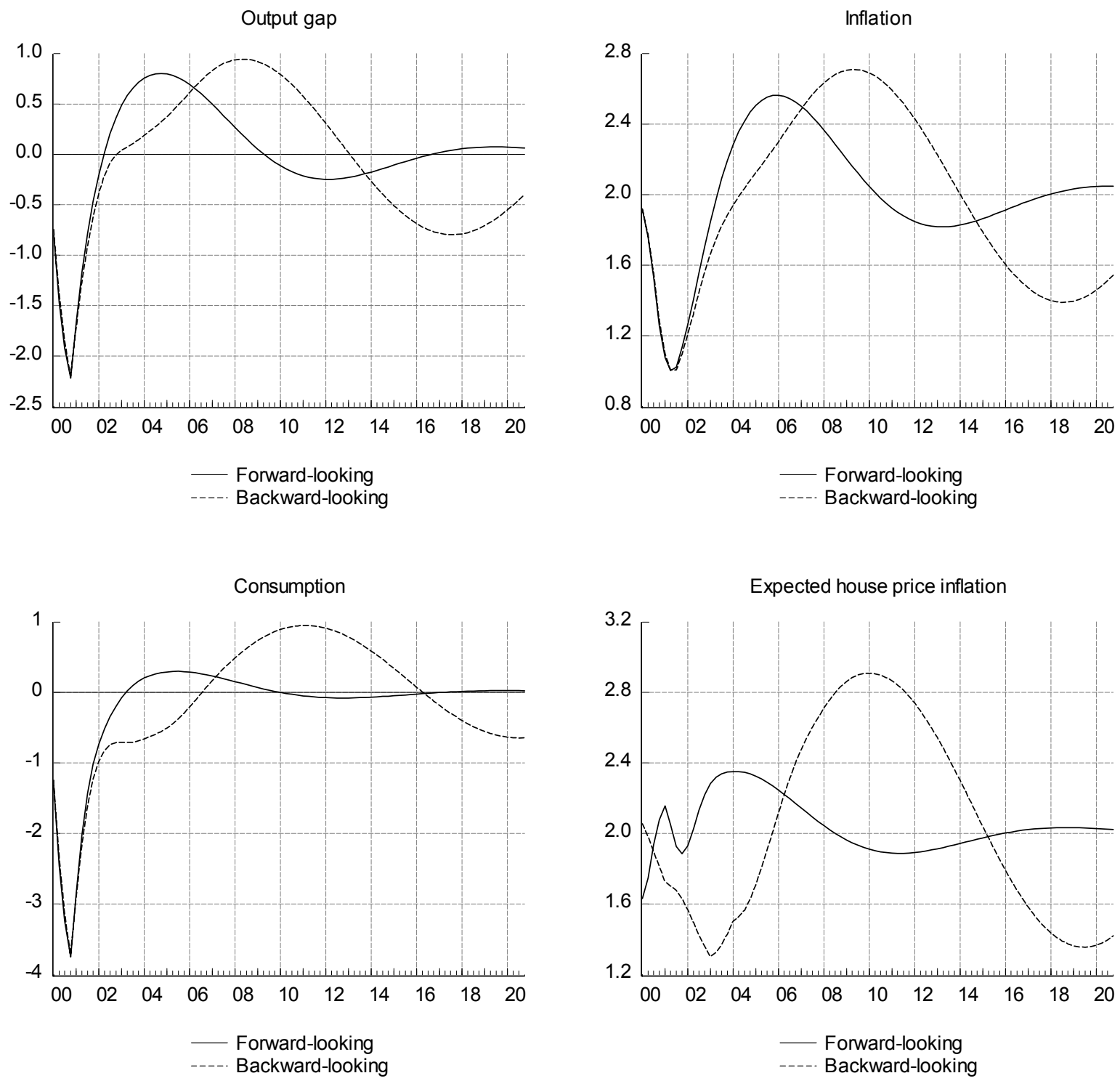

\section{The influence of wealth}

The final scenario looks at how the wealth effect influences the response of the economy. This shock consists of a permanent increase in potential output of 5\%, phased in over five years. There are two simulations with the same (50:50) backward-looking expectations as above. One has the normal wealth effect on consumption while the other sets the wealth effect to zero so that consumption is determined largely by current disposable income $\left(\alpha=1, \delta_{1}=0.67\right.$ and $\left.\delta_{2}=0\right)$. They are compared with a normal wealth effect and forward-looking house price expectations. 
With forward-looking expectations, the housing channel ensures that the increase in consumption and output to their new equilibrium levels is faster and smoother. The reduction in inflation caused by the productivity jump leads to higher real interest rates, but this effect is muted when expectations are more forward looking. Consequently, housing investment rises more quickly. Comparing the simulations with and without a wealth effect (Figure A3), the difference is not large but when expectations are partly backward looking, the economy would be better off without a wealth effect as the response is quicker and the cycles damp down faster. The combination of extrapolative expectations and a strong wealth effect can be destabilising.

Figure A3. Wealth effects with different expectations mechanisms
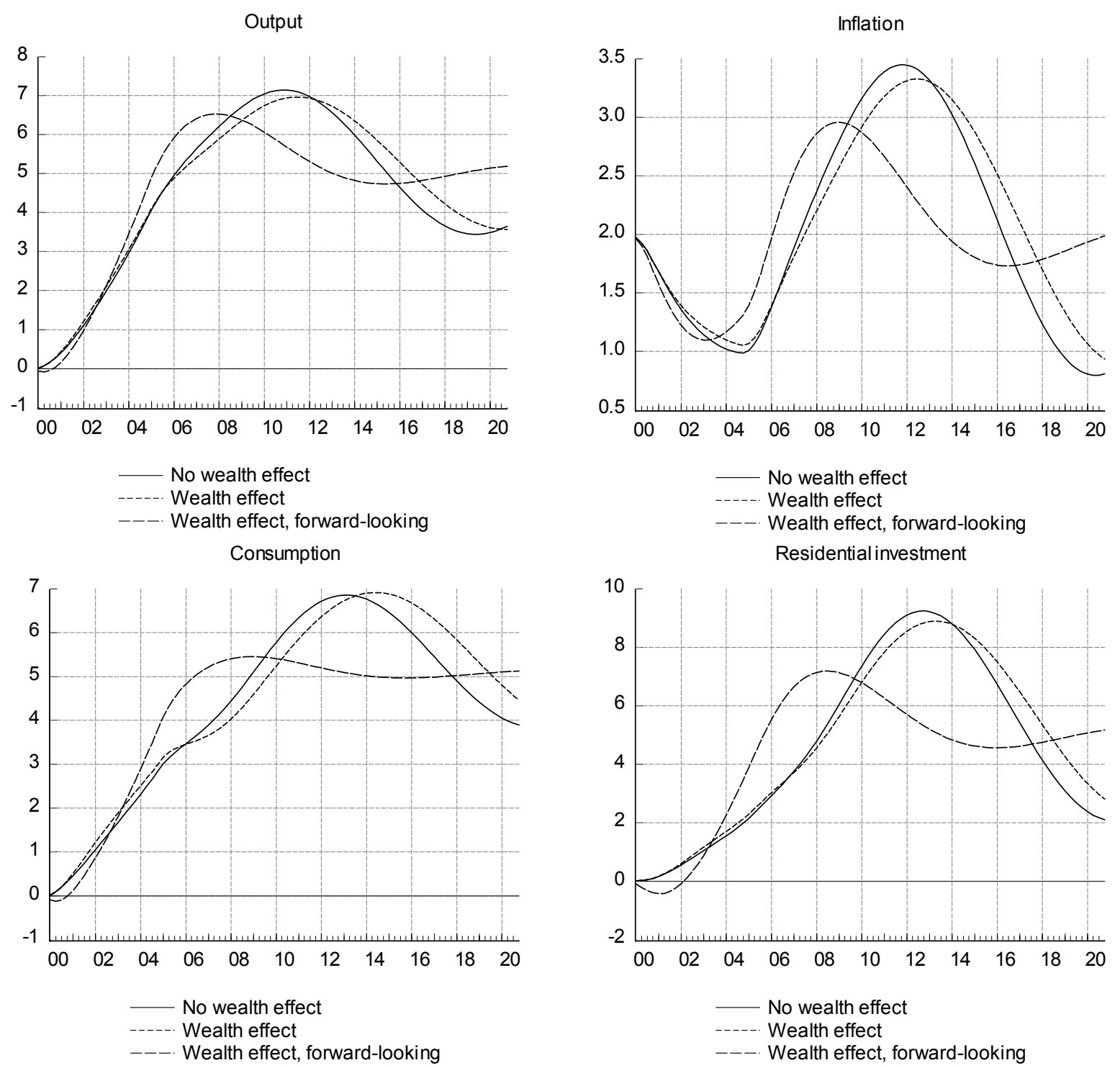


\section{BIBLIOGRAPHY}

Ahearne, A., J. Ammer, B. Doyle, L. Kole and R. Martin (2005), "House Prices and Monetary Policy: A Cross-Country Study", International Finance Discussion Papers, No. 841, Board of Governors of the Federal Reserve System, Washington.

Angeloni, I., A. Kashyap and B. Mojon (2004), Monetary Policy Transmission in the Euro Area, Cambridge University Press.

Ayuso, J., D. Pérez and D. Saurina (2004), “Are Capital Buffers Pro-cyclical?”, Journal of Financial Intermediation, No. 13.

Bank of Spain (2005), "Financial Stability Report”, 05/2005.

Barker, K. (2006), Barker Review of Land Use Planning. Interim Report - Analysis, London.

Baunkjoer, C. (2004), "Housing Taxation”, in M. Lujanen (ed.), Housing and Housing Policy in Nordic Countries, Nordic Council of Ministers.

Bikker, J. A. and P.A.J. Metzemakers (2003), "Bank Provisioning Behaviour and Procyclicality", DNB Staff Reports, No. III/2003.

Borio, C. (2003), “Towards a Macroprudential Framework for Financial Supervision and Regulation”, BIS Working Papers, No. 128.

Casolaro, L., L. Gambacorta and L. Guiso (2005), "Regulation, Formal and Informal Enforcement and the Development of the Household Loan Market. Lessons from Italy", Banca d'Italia Temi di Discussione del Servicio Studi, No. 560.

Catte, P., N. Girouard, R. Price and C. André (2004), "Housing Markets, Wealth and the Business Cycle", OECD Economics Department Working Papers, No. 394.

Chiuri, M. C. and T. Japelli (2001), "Financial Market Imperfections ad Home Ownership: A Comparative Study", CEPR Discussion Paper, No. 2717.

Cournède, B., A. Janovskaia and P. van den Noord (2005), "Sources of Inflation Persistence in the Euro Area”, OECD Economics Department Working Papers, No. 435, Paris.

Deroose, S., S. Langedijk and W. Roeger (2004), "Reviewing Adjustment Dynamics in EMU: from Overheating to Overcooling", European Economy, Economic Papers, No. 198.

Dobson, W. and G.C. Hufbauer (2001), World Capital Markets. Challenges for the G-10, Institute for International Economics, Washington. 
Drew, A., M. Kennedy and T. Sløk (2004), "Differences in Resilience Between the Euro Area and US Economies", OECD Economics Department Working Papers, No. 382, Paris.

Duval, R. (2007) "The Role of Policies and Institutions for Economic Resilience to Shocks: A Panel Data Analysis", OECD, forthcoming.

EC (2005), Quarterly Report on the Euro Area, III/2005.

EC (2006a), Quarterly Report on the Euro Area, I/2006.

EC (2006b), "Adjustment Dynamics in the Euro Area: Experiences and Challenges”, EU Economy 2006 Review.

ECB (2006a), "Recent Developments in Supervisory Structures in EU and Acceding Countries”, October.

ECB (2006b), “The EU Arrangements for Financial Crises Management”, In: Financial Stability Review, December.

European Mortgage Federation (2006), "EMF Study on Interest Rate Variability in Europe”, Brussels, July.

Eisenbeis, R.A. and G.G. Kaufman (2006), "Cross-Border Banking: Challenges for Deposit Insurance and Financial Stability in the European Union", Paper presented at the Third Annual DG ECFIN Research Conference on Adjustment under monetary union: Financial market issues, 7-8 September 2006.

Erlandsen, E., J. Lundsgaard and F. Huefner (2006), "The Danish Housing Market: Less Subsidy and more Flexibility”, OECD Economics Department Working Papers, No. 513.

Eschenbach F. and L. Schuknecht (2002), "The Fiscal Costs of Financial Instability Revisited”, ECB Working Paper, No. 191.

Fernández de Lis, S., J. Martinez Pagés and S. Saurina (2001), “Credit Growth, Problem Loans and Credit Risk Provisioning in Spain", in: Marrying the Macro- and Microprudential Dimensions of Financial Stability, BIS Papers, No. 1, Basel.

Girouard, N. and S. Blondal (2001), "House Prices and Economic Activity", OECD Economics Department Working Papers, No. 279.

Girouard, N., M. Kennedy, P. van den Noord and C. André (2006a), "Recent House Price Developments: the Role of Fundamentals", OECD Economics Department Working Papers, No. 475.

Girouard, N., M. Kennedy and C. André (2006b), "Has the Rise in Debt Made Households More Vulnerable?", OECD Economics Department Working Papers, No. 555.

Giuliodori, M. (2005), "The Role of House Prices in the Monetary Transmission Mechanism across European Countries", Scottish Journal of Political Economy, Vol. 52, No.4.

Glaeser, E., J. Gyourko and R. Saks (2005), “Why Have Housing Prices Gone Up”, NBER Working Paper, No. 11129. 
Green, R.K. and S. Wachter (2005), "The American Mortgage in International Context", Journal of Economic Perspectives, Vol. 19, No. 4.

Gulde, A.-M. and H. C. Wolf (2005), "Financial Stability Arrangements in Europe: A Review", Proceedings of OeNB Workshops, No. 4/2005, Austrian Central Bank.

Henley, A. and Morley, B. (2001) "European House Price Volatility and the Macroeconomy: The Implications for European Monetary Union", Aberystwyth: University of Wales, School of Management and Business.

HM Treasury (2003), Housing, Consumption and EMU, London.

Hoeller, P., C. Giorno and C. de la Maisonneuve (2002), "Overheating in Small Euro Area Economies: Should Fiscal Policy React?”, OECD Economics Department Working Papers, No. 323.

Iacoviello, M. (2000) "House Prices and the Macroeconomy in Europe: Results from a Structural VAR Analysis", ECB Working Paper No. 18, Frankfurt.

IMF (2006), “Euro Area Policies: Selected Issues”, IMF Country Report, No. 06/288.

Jokipii, T. and A. Milne (2006), "The Cyclical Behaviour of European Bank Capital Buffers", Bank of Finland Research Discussion Papers, No. 17.2006.

Kennedy, N. and Andersen, P. (1994), "Household Saving and Real House Prices: An International Perspective". Bank for International Settlements Working Paper No. 20.

Lane, P. R. (2004), “Assessing Ireland's Price and Wage Competitiveness”, Economics Department, Trinity College, Dublin.

Lindquist, K. (2004), “Banks’ Buffer Capital: How Important is Risk?”, Journal of International Money and Finance, 23(3).

Lowe, P. (2002), “Credit Risk Measurement and Procyclicality”, BIS Working Papers, No. 116.

Maclennan, D., J. Muellbauer and M. Stephens (1998), “Asymmetries in Housing and Financial Market Institutions and EMU”, Oxford Review of Economic Policy, 14(3).

Muellbauer, J. (2005), "Property Taxation and the Economy after the Barker Review", The Economic Journal, Vol. 115, No. 502.

Van den Noord, P. (2005), "Tax Incentives and House Price Volatility in the Euro Area: Theory and Evidence", Economie internationale, No. 101.

OECD (2003a), Economic Survey of Spain, Paris.

OECD (2004), Economic Survey of the Netherlands, Paris.

OECD (2006a), Economic Survey of the Euro Area, Paris.

OECD (2006b), Economic Survey of Finland, Paris.

OECD (2006c), Economic Survey of Spain, Paris. 
Posen, A. (2003), "It Takes More Than a Bubble to Become Japan", in Asset Prices and Monetary Policy, edited by A. Richards, Reserve Bank of Australia.

Rae, D. and P. van den Noord (2006), "Ireland's Housing Boom: What Has Driven it and Have Prices Overshot?", OECD Economics Department Working Papers, No. 492.

Roubini, N. (2006), "Why Central Banks Should Burst Bubbles”, International Finance, Vol. 9.

Sala-i-Martin, X. (1996), "Regional Cohesion: Evidence and Theories of Regional Growth and Convergence", European Commission Economic Papers, No. 226.

Saks, R. (2005), “Job Creation and Housing Construction: Constraints on Metropolitan Area Employment Growth", Finance and Economics Discussion Series, Federal Reserve Board, 2005-49.

Swank, J., J. Kakes and A.F. Tieman (2002), "The Housing Ladder, Taxation and Borrowing Constraints", De Nederlandsche Bank Staff Reports, No. 9.

Vartia, L. (2006), "Finland's Housing Market: Reducing Risks and Improving Policies", OECD Economics Department Working Papers, No. 514.

Weber, A. and G. Beck (2005), "Price Stability, Inflation Convergence and Diversity in EMU: Does One Size Fit All?", Center for Financial Studies, Frankfurt. 


\section{WORKING PAPERS}

The full series of Economics Department Working Papers can be consulted at www.oecd.org/eco/Working_Papers/

549. Financial markets in Iceland (March 2007) Peter Tulip

548. The political economy of delaying fiscal consolidation (March 2007) Boris Cournède

547. The impact on growth of higher efficiency of public spending on schools (March 2007) Frédéric Gonand

546. Performance indicators for public spending efficiency in primary and secondary education (February 2007) Douglas Sutherland, Robert Price, Isabelle Joumard and Chantal Nicq.

545. Monetary policy and macroeconomic stability in Latin America: the cases of Brazil, Chile, Colombia and Mexico (February 2007) Luiz de Mello and Diego Moccero

544. The Brazilian "tax war": the case of value-added tax competition among the states (February 2007) Luiz de Mello

543. Public spending efficiency: institutional indicators in primary and secondary education (January 2007) Frédéric Gonand, Isabelle Joumard and Robert Price

542. Enhancing turkey's growth prospects by improving formal sector business conditions (January 2007) Rauf Gönenç, Willi Leibfritz, Gökhan Yilmaz

541. Fiscal relations across levels of government in Australia (January 2007) Vassiliki Koutsogeorgopoulou

540. Russian manufacturing and the threat of 'Dutch Disease': A comparision of competitiveness developments in Russia and Ukrainian industry

(January 2007) Rudiger Ahrend, Donato de Rosa and William Tompson

539. Stimulating innovation in Russia: The role of institutions and policies (January 2007) Christian Gianella and William Tompson

538. Healthcare reform in Russia: problems and prospects (January 2007) William Tompson

537. A golden rule for Russia? How a rule-based fiscal policy can allow a smooth adjustment to the new terms of trade

(January 2007) Christian Gianella

536. From "clientelism" to a "client-centred orientation"? The challenge of public administration reform in Russia (January 2007) William Tompson

535. Has the rise in debt made households more vulnerable?

(December 2006) Nathalie Girouard, Mike Kennedy and Christophe André

534. Social security reform in Brazil: Achievements and remaining challenges (December 2006) Fabio Giambiagi and Luiz de Mello

533. Improving labour utilisation in Brazil 


\section{ECO/WKP(2007)10}

(December 2006) Luiz de Mello, Naércio Menezes Filho and Luiz G. Scorzafave

532. Boosting innovation performance in Brazil

(December 2006) Carlos H. de Brito Cruz and Luiz de Mello

531. Consolidating macroeconomic adjustment in Brazil

(December 2006) Luiz de Mello and Diego Moccero

530. Product market regulation in the non-manufacturing sectors of OECD countries: Measurement and highlights (December 2006) Paul Conway and Giuseppe Nicoletti

529. The Turkish pension system: further reforms to help solve the informality problem (November 2006) Anne-Marie Brook and Edward Whitehouse

528. Policies to improve Turkey's resilience to financial market shocks (November 2006) Anne-Marie Brook.

527. Upgrading Japan's innovation system to sustain economic growth (November 2006 Randall S. Jones and Tadashi Yokoyama

526. Strengthening the integration of Japan in the world economy to benefit more fully from globalisation (November 2006) Randall S. Jones and Taesik Yoon

525. OECD's FDI regulatory restrictiveness index: Revision and extension to more economies (November 2006) Sven Blöndal and Alain de Serres

524. Globalisation and inflation in the OECD economies (November 2006) Nigel Pain, Isabell Koske and Marte Sollie

523. Identifying determinants of Germany's international price competitiveness - A structural VAR approach (November 2006) Martin Meurers

522. Short-term pain for long-term gain: the impact of structural reform on fiscal outcomes in EMU (November 2006) Paul van den Noord and Boris Cournède

521. Interactions between monetary and fiscal policy: How monetary conditions affect fiscal consolidation (November 2006) Rudiger Ahrend, Pietro Catte and Robert Price

520. Restoring fiscal sustainability in the Euro Area: raise taxes or curb spending? (October 2006) Boris Cournède and Frédéric Gonand

519. Should Measures of Fiscal Stance be Adjusted for Terms of Trade Effects (October 2006) David Turner

518. Monetary policy and inflation expectations in Latin America: Long-run effects and volatility spillovers (October 2006) Luiz de Mello and Diego Moccero

517. Social safety nets and structural adjustment (September 2006) Paul van den Noord, Nathalie Girouard and Christophe André

516. Adapting the Icelandic education system to a changing environment (September 2006) Hannes Suppanz

515. Forecasting monthly GDP for Canada (September 2006) Annabelle Mourougane 